WORKING PAPER

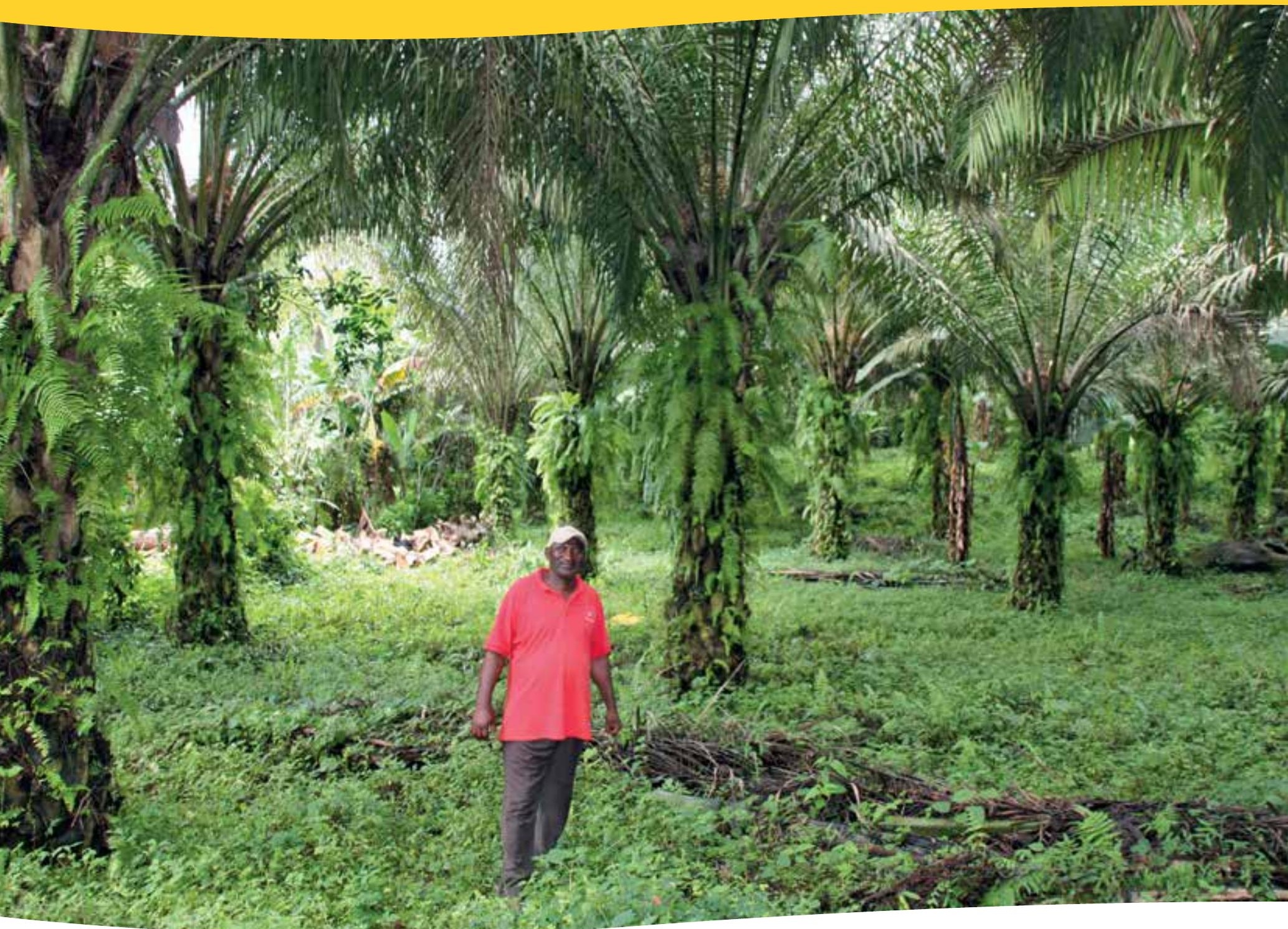

\title{
The non-industrial palm oil sector in Cameroon
}

Raymond Ndip Nkongho

Laurène Feintrenie

Patrice Levang

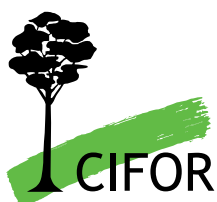



Working Paper 139

\section{The non-industrial palm oil sector in Cameroon}

Raymond Ndip Nkongho

Center for International Forestry Research (CIFOR)

\section{Laurène Feintrenie}

CIRAD (French Agricultural Research Centre for International Development)

Research Unit Forest Goods and Ecosystem Services (B\&SEF)

\section{Patrice Levang}

Institut de Recherche pour le Développement (IRD-GRED)

Center for International Forestry Research (CIFOR) 
Working Paper 139

(c) 2014 Center for International Forestry Research

Content in this publication is licensed under a Creative Commons Attribution-NonCommercial-NoDerivs 3.0 Unported License http://creativecommons.org/licenses/by-nc-nd/3.0/

Nkongho RN, Feintrenie L and Levang P. 2014. The non-industrial palm oil sector in Cameroon. Working Paper 139. Bogor, Indonesia: CIFOR.

Photos by Patrice Levang (IRD/CIFOR)

Cover photo by Patrice Levang (IRD/CIFOR)

Smallholder oil palm plantation in Muyuka, Southwest Cameroon.

CIFOR

Jl. CIFOR, Situ Gede

Bogor Barat 16115

Indonesia

$\mathrm{T}+62(251) 8622-622$

$\mathrm{F}+62(251) 8622-100$

E cifor@cgiar.org

\section{cifor.org}

We would like to thank all donors who supported this research through their contributions to the CGIAR Fund. For a list of Fund donors please see: https://www.cgiarfund.org/FundDonors

Any views expressed in this book are those of the authors. They do not necessarily represent the views of CIFOR, the editors, the authors' institutions, the financial sponsors or the reviewers. 


\section{Table of contents}

Acknowledgements $\quad$ v

1 Introduction 1

2 Methodology 4

3 Results $\quad 6$

3.1 Characteristics of palm oil producers $\quad 6$

$\begin{array}{ll}3.2 & \text { Sources of income of palm oil producers }\end{array}$

$\begin{array}{ll}3.3 & \text { Differentiated access to land }\end{array}$

3.4 Reduced conversion of primary forest $\quad 8$

3.5 Management of an oil palm plantation 9

3.6 Labor $\quad 12$

3.7 Economic results 13

$\begin{array}{lll}3.8 & \text { Future plans for palm oil producers } & 15\end{array}$

4 Discussion $\quad 16$

4.1 Strengths and weaknesses of the sector 16

$\begin{array}{ll}4.2 & \text { Learning from other countries } \\ 4.3 & 17\end{array}$

4.3 Elites' role in oil palm development $\quad 18$

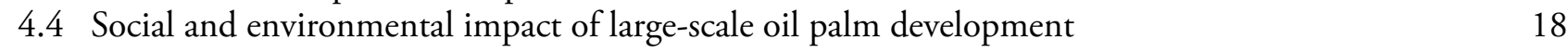

5 Conclusion $\quad 20$

6 References $\quad 21$ 


\section{List of tables and figures}

\section{Tables}

1 Average areas (ha) per household per category of palm oil producers. $\quad 8$

2 Field operational costs for the establishment and upkeep of a hectare of oil palm plantation. $\quad 10$

3 Fertilizer application by different types of palm oil producers. 11

4 The variable cost incurred for the artisanal processing of a ton of oil palm FFB. 14

5 Revenue derived from the sale of FFB and red palm oil (in Euros). 15

\section{Figures}

1 Location of study sites in Cameroon. $\quad 4$

2 Agro-ecological suitability to oil palm cultivation. 5

3 Age distribution of different types of palm oil producers. 6

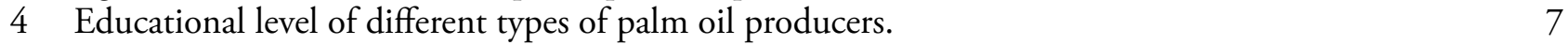

5 Distribution of areas for different types of palm oil producers. $\quad 8$

6 Controlled pollination of the female inflorescence of oil palm in IRAD La Dibamba. 12

7 Production of quality seeds at IRAD La Dibamba. 12

8 Nursery of an elite palm oil producer. 12

9 "Smallholder" oil palm plantation in Eseka (Centre Region). 12

10 Harvested FFB ready for artisanal milling.

11 Milling of boiled fruits to produce crude palm oil. 14

12 Red palm oil ready for consumption after clarification. $\quad 14$

13 Makeshift bridge leading to a smallholder oil palm plantation. 15 


\section{Acknowledgements}

The authors are grateful to the CGIAR Research Program on Forests, Trees and Agroforestry (http:// www.cifor.org/forests-trees-agroforestry) for their support and to ANR (French National Research Agency) for their support through the Sustainable
Palm Oil Project (SPOP) (http://spop.cirad. fr). We would also like to thank all donors who supported this research through their contributions to the CGIAR Fund (https://www.cgiarfund.org/ FundDonors). 



\section{Introduction}

Oil palm (Eleis guineensis Jacq.) is not new to Cameroon, since it is indigenous to the countries bordering the Gulf of Guinea. People in the rainforest region of Cameroon used to harvest fresh fruit bunches (FFB) from the wild dura variety to produce palm oil and kernel oil, and fell and tap old stands of both dura and pisifera varieties to produce palm wine, which is a much cherished liquor. The hybrid tenera oil palm variety produces the highest yield — up to eight times more-compared to other vegetable oil crops like soybean, sunflower or rapeseed (Mathew et al. 2007; Feintrenie and Rafflegeau 2012; Jacquemard 2012).

According to agro-ecological data from IRAD (Institut de Recherche Agronomique pour le Développement) and the Cameroon Statistic Directory, five of Cameroon's ten regions are suitable for oil palm cultivation. These five regions include: the Southwest, Littoral, South, Center and East regions; with respect to rainfall, the most suitable regions for oil palm cultivation include Southwest, Littoral, part of Center (Nyong et Kelle Division) and part of South (Ocean Division). This also partly explains why all the oil palm agro-industries are located in the latter (Cf. fig $1 \& 2$ ). All five regions are located in the humid tropical part of the country and are noted for having suitable climate and soil conditions for oil palm cultivation. Littoral, Southwest and Centre regions host a significant number of palm oil producers and present a longstanding historical relationship between smallholders and major agro-industrial companies like the Cameroon Development Cooperation (CDC), Pamol and Socapalm. Four major palm oil production basins were developed in relation to the three major palm oil companies. These basins are Dibombari (Littoral), Eseka (Center), Muyuka (Southwest) and Lobe/ Mundemba (Southwest). The main enterprises located in these zones include Socapalm (Dibombari and Eseka), CDC (Muyuka) and Pamol (Lobe/ Mundemba) (Cf. fig 1).

Five agro-industries are involved in the production of crude palm oil in Cameroon. These agroindustries include "Société des Palmeraies de la Ferme Suisse (SPFS)" established in 1907, Pamol established in 1928, CDC established in 1947/48,
"Société Africaine Forestière et Agricole du Cameroun (SAFACAM)" established in 1897 as a rubber company and effectively started cultivating oil palm in 1959, and "La Société Camerounaise de Palmeraies" (SOCAPALM) established in 1968. Today, three of these agro-industries; SPFS, Safacam and Socapalm are private companies managed by the Bolloré group, while Pamol and CDC are public companies.

During the first palm oil development plan in 1977/78, the government of Cameroon as part of its poverty reduction strategy, thought it wise to establish the smallholder oil palm sector by providing quality planting material, inputs and technical expertise to smallholders through major oil palm companies like Pamol, CDC and Socapalm, with funds from the World Bank, under the control of Fonds National du Développement Agricole (FONADER). This gave birth to what is usually called the first generation of oil palm smallholders. With the collapse of FONADER in the early 1990s due to the economic crisis, a new generation of palm oil producers (second generation) emerged with larger plantation surface areas (Konings 1986). The under-contract oil palm smallholders are those established in the late 1970s with funds from FONADER (Elong 2003), and comprise many plasma or satellite oil palm plantations surrounding the nucleus mill. The plasma plantations (plantations owned by smallholders, but developed by agroindustries with funds from FONADER) comprise 2-5 ha oil palm plantations established within a maximum distance of $30 \mathrm{~km}$ from the companies' nucleus mill, on an in-kind credit basis by the aforementioned companies to selected oil palm smallholders who showed proof of land ownership. The smallholders were to supply the labor force, while the company had to deliver quality planting material, essential inputs like fertilizers, pesticides and fungicides together with technical skills to the smallholders. In return, the smallholder was supposed to deliver all the harvested FFB to the company's nucleus mill as soon as the palms matured and a percentage was deducted from the sales to reimburse the credit from FONADER. These smallholders are no longer under formal contract with any of the companies, and the supply of bunches to the nucleus 
mill is at the discretion of the smallholder during peak and low season. The independent palm oil producers are self-funded oil palm growers, installed within or out of basins carved out during the first oil palm development plan in the late 1970s. These categories of palm oil producers need to harvest and process their FFB themselves because of their distance from the industrial mills, which additionally increases the profitability of their oil palm plantation through the highest added value of palm oil over the sale of FFB.

History holds that oil palm was taken from Africa and then introduced to Latin America and Southeast Asia by the end of the 19th century. Today Indonesia and Malaysia alone produce $85 \%$ of the world's crude palm oil (CPO), while Cameroon stands at the 13th position in terms of world production of CPO (www. indexmundi.com).

According to Hoyle and Levang (2012), Cameroon produced 230,000 tons of CPO in 2010 across an estate of approximately $190,000 \mathrm{ha}$. The production of CPO in Cameroon is distributed across three plantation types:

- Agro-industrial plantations: 58,860 ha producing 120,000 tons CPO;

- Under-contract private plantations: 35,000 ha producing 30,000 tons CPO (plantations developed during the FONADER period);

- Independent palm oil producers: occupying an estimated 100,000 ha producing approximately 80,000 tons $\mathrm{CPO}$.

The terms "oil palm smallholders" and "plantations villageoises" are both used in Cameroon to describe the individual ownership of an oil palm plantation. Both terms are inadequate as some holdings can be rather large (up to $1000 \mathrm{ha}$ ), and none of these holdings are village owned (Bakoumé 2006; Levang and Nkongho 2012). Even if RSPO (the Roundtable on Sustainable Palm Oil - www.rspo.org) defines smallholders as farmers with less than 50 ha of oil palm, other studies consider the smallholder upper limit with a 5 ha threshold. A more appropriate partitioning would be: smallholders ( $0-5 \mathrm{ha})$, medium-holders (5-20 ha) and large-holders (more than $20 \mathrm{ha}$ ) based on the size of the plantation and the management prerogative likely to be put in place by the oil palm grower. Thus, the best wording would be "non-industrial oil palm plantations". For greater convenience we will hereafter use "palm oil producers", "oil palm planters" or "oil palm growers" , when referring to all kinds of non-industrial oil palm plantations. Previous studies have stressed the massive involvement of elites in the development of oil palm plantations especially after the collapse of the FONADER-sponsored smallholder scheme that was designed for poor farmers and the advent of the economic crisis in the early 1990 (Elong 2003; Ngambi et al. 2011; Obam and Elong 2011; Obam and Tchonang Goudjou 2011; Levang and Nkongho 2012). The yield of oil palm in Cameroon is not distributed evenly in the course of the year and it takes 5.5-6 months for the female inflorescence pollinated by the palm weevil Elaidobius kamerunicus to become fully mature and ready for harvesting (Syed 1982; Hornus et al. 1987). There are three distinct seasons of production: these include the lowproduction season, which falls within the months June to September; the mid-peak period, which falls within the months October to January; and the peak period which falls within the months of February to May. A hectare of oil palm plantation yielding 8 tFFB/ha/year, can generate 5 tons FFB during the peak production season, 2 tons FFB during the midpeak season and 1 ton FFB during the low season. These marked differences in production are linked to the dry spell experienced from November to February amongst other biophysical factors (Offah Tabot, Estate Manager CDC, pers. com.). Recent climatic changes have also distorted the smooth transition from dry to rainy season, in some cases leading to prolonged periods of drought. When the rain finally comes, it is occasionally intense and above field capacity, leading to leaching and runoffs. All of these variations have detrimental effects on subsequent yields. In order to reach optimal production of 20 to 25 tons $\mathrm{FFB} /$ ha/year with respect to prevailing West African conditions, the oil palm requires the following biophysical conditions: high temperatures all year round, between $25-28^{\circ} \mathrm{C}$; sufficient sunshine, at least 5 hours of sun per day; high rainfall, evenly distributed between 1800-2400 mm/year without dry spells of more than 90 days; rich soil, but can also adapt to poor soils with adequate use of fertilizer; low altitude, ideally below $500 \mathrm{~m}$ asl.

In Cameroon, three-quarters of the total oil palm area is in the hands of the non-industrial palm oil sector, but this provides only half of the production due to very low yields $(<1$ ton $\mathrm{CPO} / \mathrm{ha} / \mathrm{yr})$. This low yield is not only limited to palm oil producers as some agro-industries like CDC and Pamol cannot afford to produce up to 2 tons $\mathrm{CPO} / \mathrm{ha} / \mathrm{yr}$. In contrast, in Indonesia smallholders reach much better yields (3-3.5 tons $\mathrm{CPO} / \mathrm{ha} / \mathrm{yr}$ ) with guaranteed purchase ensured by agro-industries (Hoyle and Levang 2012). 
Cameroon has a huge domestic and sub-regional market for the sale of $\mathrm{CPO}$, but despite this advantage, the country is a net importer of CPO with an estimated import of 50,000 tons in 2011 and 80,000 tons in 2012 (E. Ngom, Minader, pers. com.). According to Ngando et al. (2011), $80 \%$ of Cameroonians consume red palm oil with an estimated $30 \%$ produced by artisanal mills.

According to Carrère (2010), the advantages of these "oil palm smallholdings" could be numerous, since these holdings can guarantee growers a stable income, foster land tenure security and strengthen the monetarization of the rural areas, thus generating development. The present study seeks to carry out an evaluation of the sector with special emphasis on its current strengths and weaknesses, and on ways to overcome/solve the problems. 


\section{Methodology}

A preliminary survey of the oil palm production areas was carried out in 2011, while data collection from sampled respondents took place in 2011/2012. This preliminary survey led to the selection of four out of the seven major palm oil production basins: Eseka, Dibombari, Muyuka and Lobe/Mundemba. The location of the four selected palm oil production basins/zones is shown in figure 1, while figure 2 shows the suitability of the different regions in Cameroon to oil palm cultivation. It is interesting to note that during the FONADER-sponsored smallholder scheme, seven palm oil zones were carved out as production basins to supply FFB to major agro-industries within a $30 \mathrm{~km}$ radius of the nucleus mill. These zones included:

- Mondoni zone (Muyuka and its surroundings, smallholders in this zone were supposed to supply their FFB to the Mondoni CDC mill).

- Idenau zone (Limbe and its surroundings, smallholders in this zone were supposed to supply their FFB at the Idenau CDC mill).

- Mundemba zone (smallholders here were supposed to supply their FFB to the mill at Ndian Estate of Pamol).
- Lobe zone (smallholders here were supposed to supply their FFB to the mill at Lobe Estate of Pamol).

- Eseka zone (smallholders here were supposed to supply their FFB to Socapalm Eseka mill).

- Mbongo zone (smallholders here were supposed to supply their FFB to Socapalm Mbongo mill).

- Dibombari zone (smallholders here were supposed to supply their FFB to Socapalm mill located in Souza).

In our study, we selected four of the seven zones from the FONADER epoch. The four palm oil industrial mills considered in this study cover the two public companies (Pamol and CDC) and two mills of the Socapalm private group, which is for the time being the only private industry of the sector in Cameroon with productive plantations and mills. Thus our sample covers the variety of situations of the industrial palm oil sector in Cameroon. The four studied zones are located in the Centre (Eseka), Littoral (Dibombari) and Southwest regions of Cameroon. These regions show the densest presence of oil palm, thus the sampling can be considered as

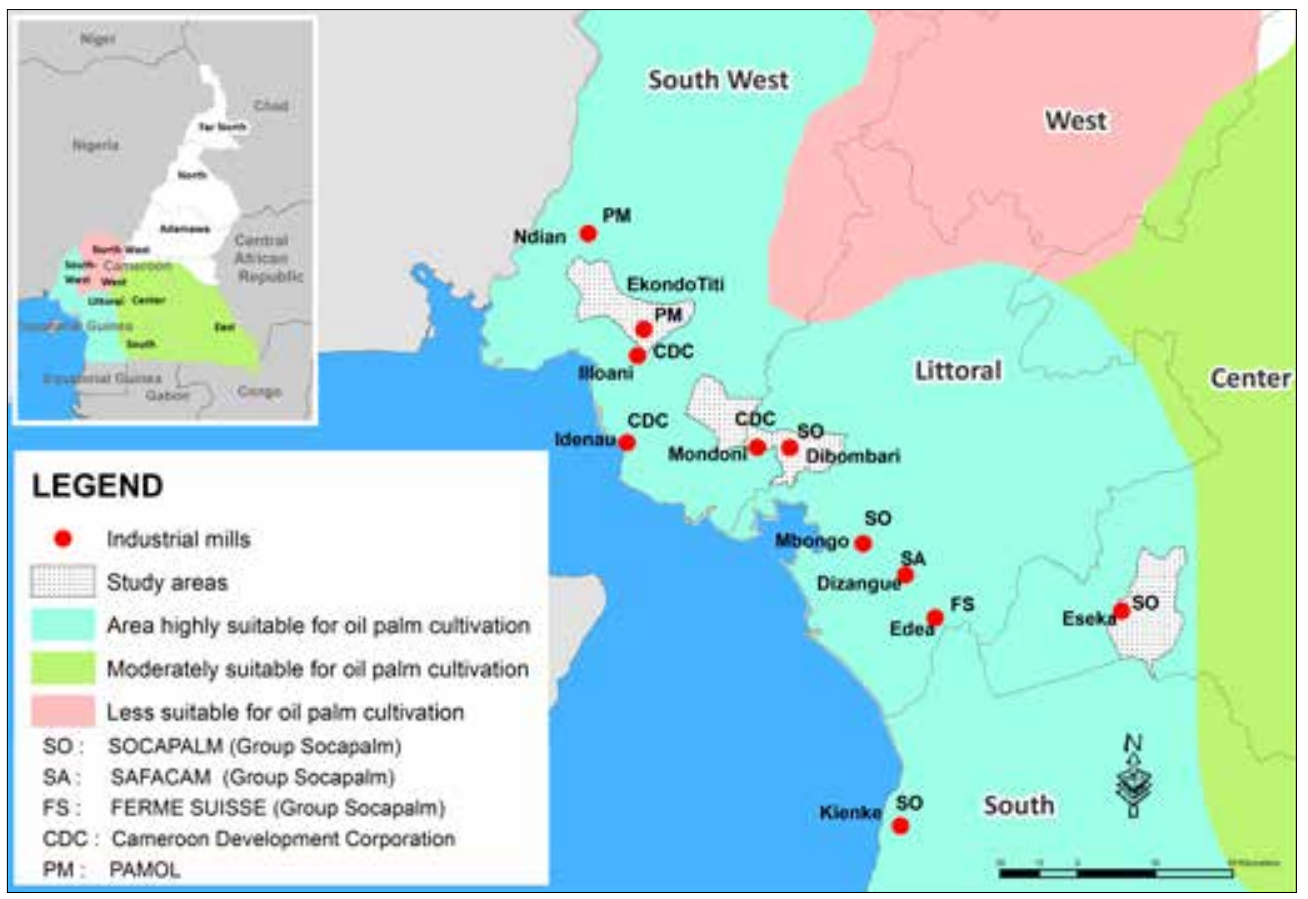

Figure 1. Location of study sites in Cameroon. 


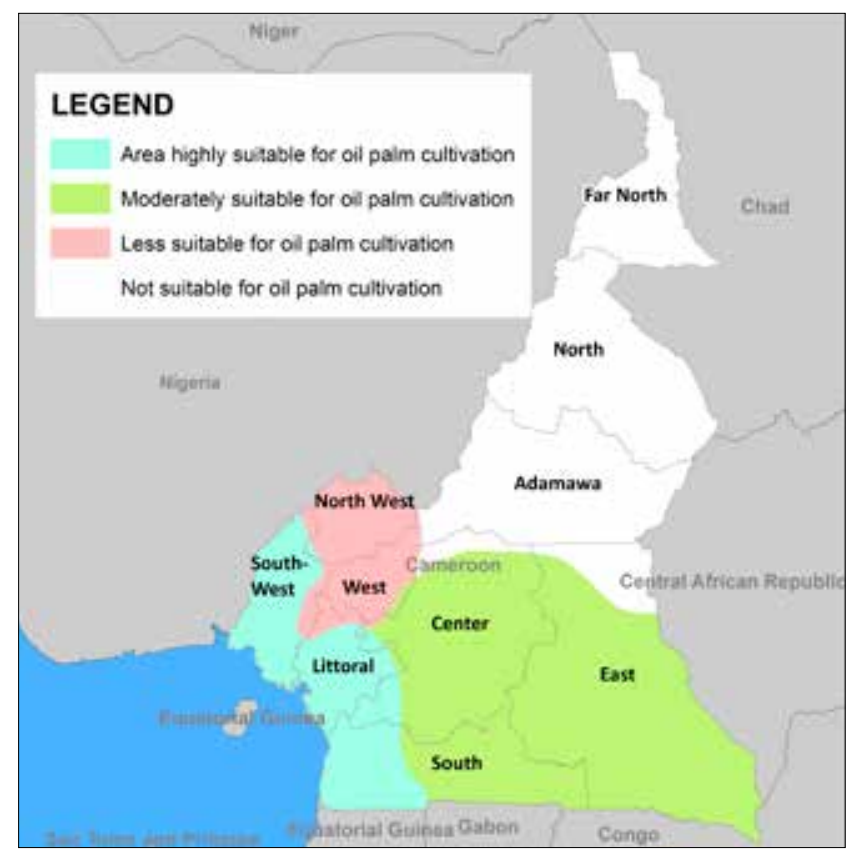

Figure 2. Agro-ecological suitability to oil palm cultivation.

representative of oil palm production in the littoral belt of Cameroon.

In the second stage, we prepared a typology of the various palm oil producers. This categorization was necessary in order to provide an overview of the activities of the different palm oil producers. Income levels, social status, place of origin, past and present work with any of the oil palm agro-industries were the main criteria used to categorize the different palm oil producers:

- Villagers (or natives): This comprises the peasant population resident in their village or clan of origin with oil palm cultivation being a major source of their livelihood.

- Non-natives (or migrants): This comprises migrants from other parts of the country who are now settled in a locality that does not belong to their forefathers.

- Company workers (past and present): This comprises people who are presently working, or have previously worked in any of the aforementioned agro-industrial companies.

- Elites (internal and external): This comprises people of high social status in their village or clan of origin. They could be resident in the village and as such are called "internal elites" like the chiefs, notables or could otherwise be termed "external elites" which implies they live outside of the village as is the case with civil servants, some businessmen, etc.
A checklist provided by the major agro-industrial companies helped in generating a stratified and randomized sample in each of the zones visited. This sampling method was necessary because the population of palm oil producers is heterogeneous and, as such, it was necessary to divide the population into subgroups. Once each subgroup was determined, a randomized sample was drawn independently. The collection of primary data was done with the use of individual semi-structured interviews, as well as semi-guided discussions. A total of 176 individual interviews was administered among four categories of producers, distributed as follows: 44 villagers (natives), 51 non-native (migrants), 40 company workers (past and present) and 41 elites. Secondary data were collected from CDC, Pamol and Socapalm, together with semiguided discussions with 45 company officials from the rank of supervisor to managerial staff, whether in active service or retired, researchers in Pamol and $\mathrm{La}$ Dibamba (IRAD) research stations, the smallholder oil palm department in the Ministry of Agriculture and Rural Development. A literature review was also conducted through internet search. The questionnaire administered to the different categories of palm oil producers was partitioned as follows:

- Identification of oil palm planter: name of producer, household rank, sex, age, ethnic group, marital status, educational level, occupation apart from oil palm cultivation.

- Farming details: previous land cover before oil palm cultivation, age of oil palm plantation, size of oil palm plantation, yield of FFB, peak-, midpeak and low-production period.

- Farm creation and management: land acquisition, procedure to get land title, the cost of establishing a hectare of oil palm plantation, origin, variety and cost of planting material, labor cost to manage oil palm plantation, cost to purchase inputs, weed control methods, major pest and diseases, cost and availability of working tools, origin of labor, stability of labor, registration of permanent labor to social security and whether the producer is a member of a common initiative group (GIC) or cooperative.

- Economic results: sale/processing of harvested FFB, net income of a hectare of oil palm plantation, sources of income for the household.

- Vision for the future: the palm oil producer's plantation, major problems that need urgent attention, proposals for the oil palm industry in Cameroon. 


\section{Results}

Eseka and Dibombari are located in the francophone part of Cameroon, with Eseka being a more "closed" agricultural zone controlled by the native Bassa people, while Dibombari shows a mixture of migrants from other parts of the country alongside the native Abbor people. Muyuka and Lobe/ Mundemba zones are home to the Balung and Oroko's natives with many immigrants from the Northwest. Dibombari and Muyuka have a good access to major markets, while Eseka and Lobe/ Mundemba are more isolated.

\subsection{Characteristics of palm oil producers}

A total of $97.2 \%$ of the sampled palm oil producers were household heads, $2.8 \%$ were non-household heads, with $93.8 \%$ of males owning oil palm plantations and just $6.2 \%$ of females owning oil palm plantations, since women are limited by customary rights and lack of capital to own oil palm plantations. In terms of age distribution, $<30$ years records the lowest number of palm oil producers, while $60+$ years records the highest number of palm oil producers, as shown in Figure 3.

Figure 3 shows that very few people under 40 years (just $10.7 \%$ ) own oil palm plantations in all the categories of sampled palm oil producers. The creation of an oil palm plantation is a huge investment, and below the age of 40 , which is termed the "youthful stage," most people who are not yet working or working without any meaningful financial reserve will not have the necessary income to invest in oil palm cultivation. Within the age range $60+$, where the highest percentage of oil palm growers falls (41\%), the dominant category of those who own oil palm plantations are former company workers, most of whom have retired. Due to their long-standing relationship with the company, they were able to acquire high quality planting material and inputs at better prices, and had technical expertise, compared to the other categories of palm oil producers. The income from the cultivation of oil palm is all year round and significantly improves household livelihood, especially at a time when the planters' benefits from their retirement are

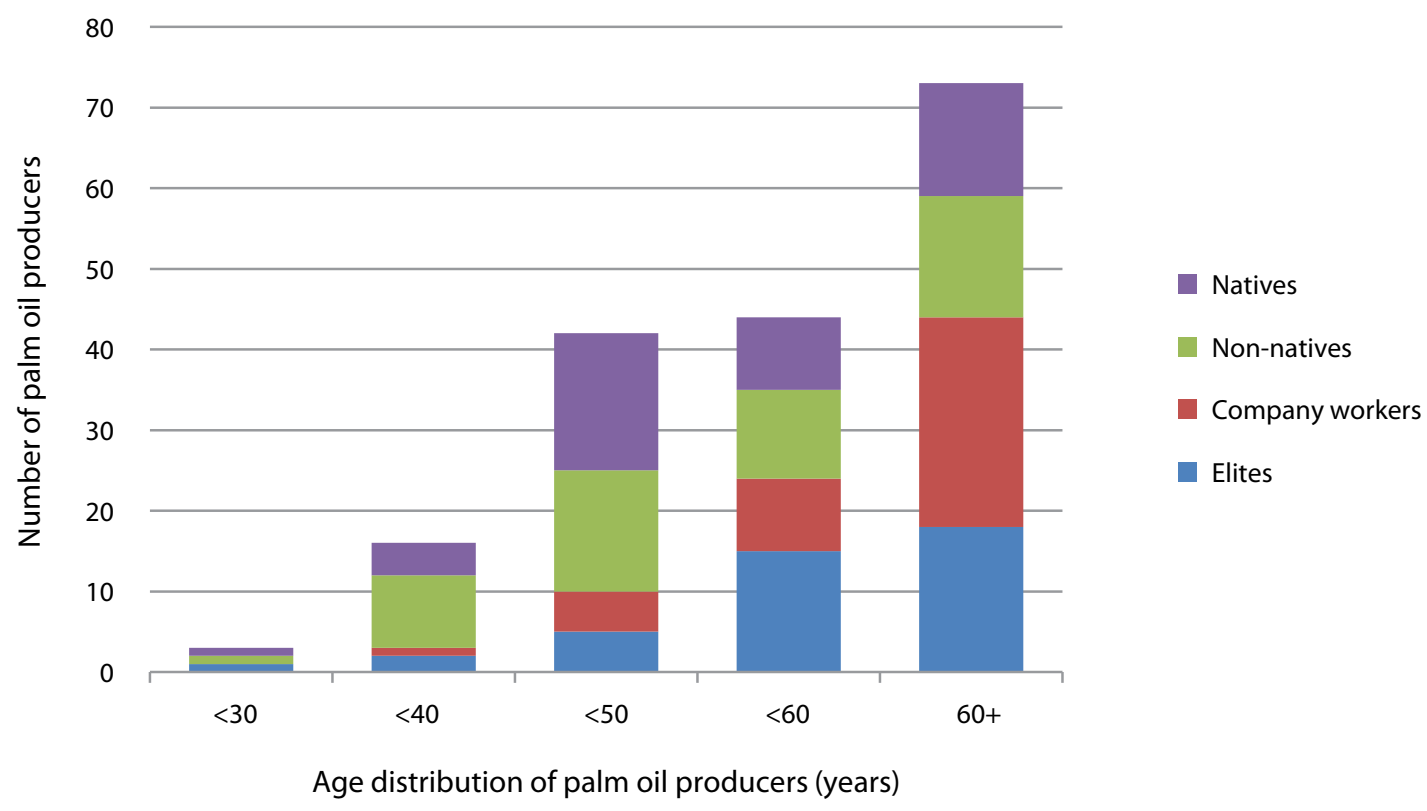

Figure 3. Age distribution of different types of palm oil producers. 
insignificant and they are no longer physically fit to embark on other income-generating activities.

As concerns educational level, $52.2 \%$ of respondents were primary school leavers, $9 \%$ were secondary school, $15.7 \%$ were high school and $23.1 \%$ held university grades. The distribution of educational level per type of smallholder is shown in Figure 4.

Figure 4 shows that primary school leavers were largely natives who had never had the opportunity to pursue their education at a post-primary level, and most of whom rely on agriculture and oil palm cultivation in particular for their livelihood. The elites, followed by non-natives or migrants, dominate the level of university graduates. These elites, because of their educational level, occupy top administrative positions in both the public and private sectors in the country. This gives them a better bargaining power in negotiation for land to cultivate oil palm, especially in their region of origin.

\subsection{Sources of income of palm oil producers}

The main occupation of these palm oil producers was as follows:

- Farming: $45.5 \%$ (rely solely on farming through the cultivation of food and cash crops as well as animal husbandry for their livelihood).

- Salaried worker: $19.7 \%$ (apart from growing oil palm, they work in either the public and private sectors of the state).
- Retired worker: $21.3 \%$ (apart from growing oil palm, they were former workers in either the public or private sectors, but are now retired).

- Trade: $7.3 \%$ (apart from growing oil palm, they also do business).

- Others: 6.2\% (apart from growing oil palm, they also perform other off-farm activities, different from those mentioned above).

The major source of income for $72 \%$ of the respondents came from the cultivation of oil palm, $7.3 \%$ got their major source of income from their salaries (off-farm activity), 3.9\% attributed their major source of income to cultivation of food crops and $2.8 \%$ attributed their major source of income to retirement benefit. The remainder were indifferent to where their major source of income came from.

It is worth noting that these producers have various sources of income and different main professions, from peasant farmers, to taxi drivers, teachers, business professionals, civil servants, up to ministers.

\subsection{Differentiated access to land}

The elites recorded the highest average areas cultivated with oil palm per household (41.3 ha). This was closely followed by the company workers (24.8 ha), the non-natives (20.7 ha) and lastly the villagers ( $8.7 \mathrm{ha})$. Concerning the availability of reserve land for future development, the elites still recorded the highest average area per household (15.1 ha), and were closely followed by the villagers (12.1 ha) as shown in Table 1. Most elites and natives

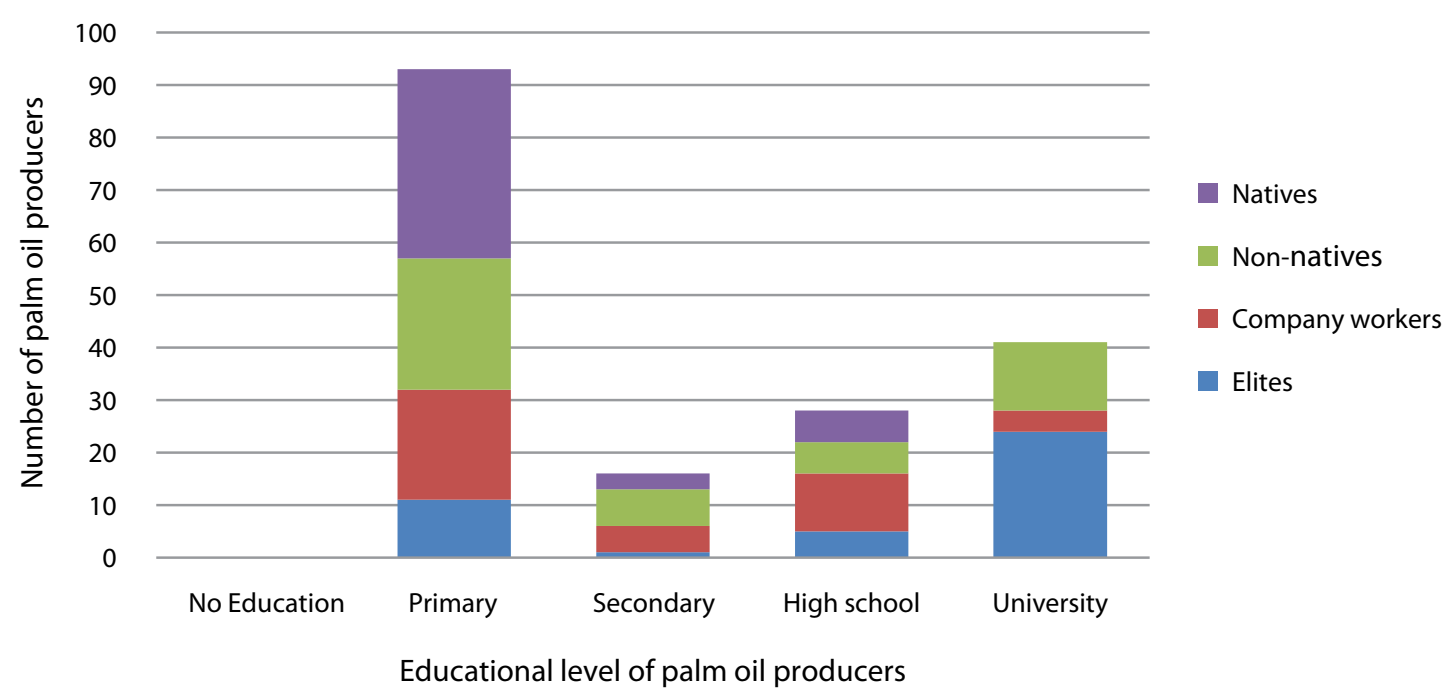

Figure 4. Educational level of different types of palm oil producers. 
are entitled to customary land rights in their areas of origin but, in contrast to the natives, most of these elites have the capital required to develop their oil palm plantation and to purchase more land for future expansion. The percentage distribution of immature, mature and old palms was $11.9 \%, 40.1 \%$ and $43.7 \%$, respectively. In the sample, $68 \%$ of the respondents bought land for the cultivation of oil palm, 33.1\% received land through inheritance and $2.2 \%$ got land through donation.

Figure 5 shows the distribution of the areas cultivated by different categories of palm oil producers, with some elites having more than 300 ha of oil palm plantations. These elites, though few in number in comparison to their peasant counterparts (natives or villagers), often own very large areas (average in the sample: $41.3 \mathrm{ha} /$ household for elites). According to a recent census of palm oil producers by Minader, 10\% of the producers were elites owning $65 \%$ of the total plantation area (Ngom, pers. comm.).

\subsection{Reduced conversion of primary forest}

Before an oil palm plantation is established, the original vegetation of that area must be removed. Previous land cover thus refers to the original vegetation cover that existed before the land was converted into oil palm cultivation. The previous land cover before conversion to oil palm cultivation was as follows:

- Primary forest: 3.9\% (untouched or logged forest never cleared for agricultural purposes to the knowledge of the farmer).

- Secondary forest: $66.9 \%$ (secondary regrowth forest of various ages after agricultural use). The dominance of secondary forest in terms of cultivated surface areas, is an indication that most areas planted with oil palm were previously used for shifting cultivation.

- Former plantation land: $17.4 \%$ (this includes areas that were formerly used for the cultivation

Table 1. Average areas (ha) per household per category of palm oil producers.

\begin{tabular}{lcccccc}
\hline & \multicolumn{5}{c}{ Average oil palm plantation surface area (ha/household) } \\
\cline { 2 - 7 } & Young palms & Mature palms & Old palms & Total palms & $\begin{array}{c}\text { Undeveloped } \\
\text { land }\end{array}$ & $\begin{array}{c}\text { Total land } \\
\text { Ownership }\end{array}$ \\
\hline Elite & 6.8 & 21.1 & 13.4 & 41.3 & 15.1 & 56.4 \\
Company worker & 1.4 & 5.4 & 18.0 & 24.8 & 6.7 & 31.5 \\
Non-native & 2.0 & 10.1 & 8.6 & 20.7 & 3.9 & 24.6 \\
Native & 1.7 & 3.5 & 3.7 & 8.7 & 12.5 & 21.2 \\
\hline
\end{tabular}

Source: 2011 field survey

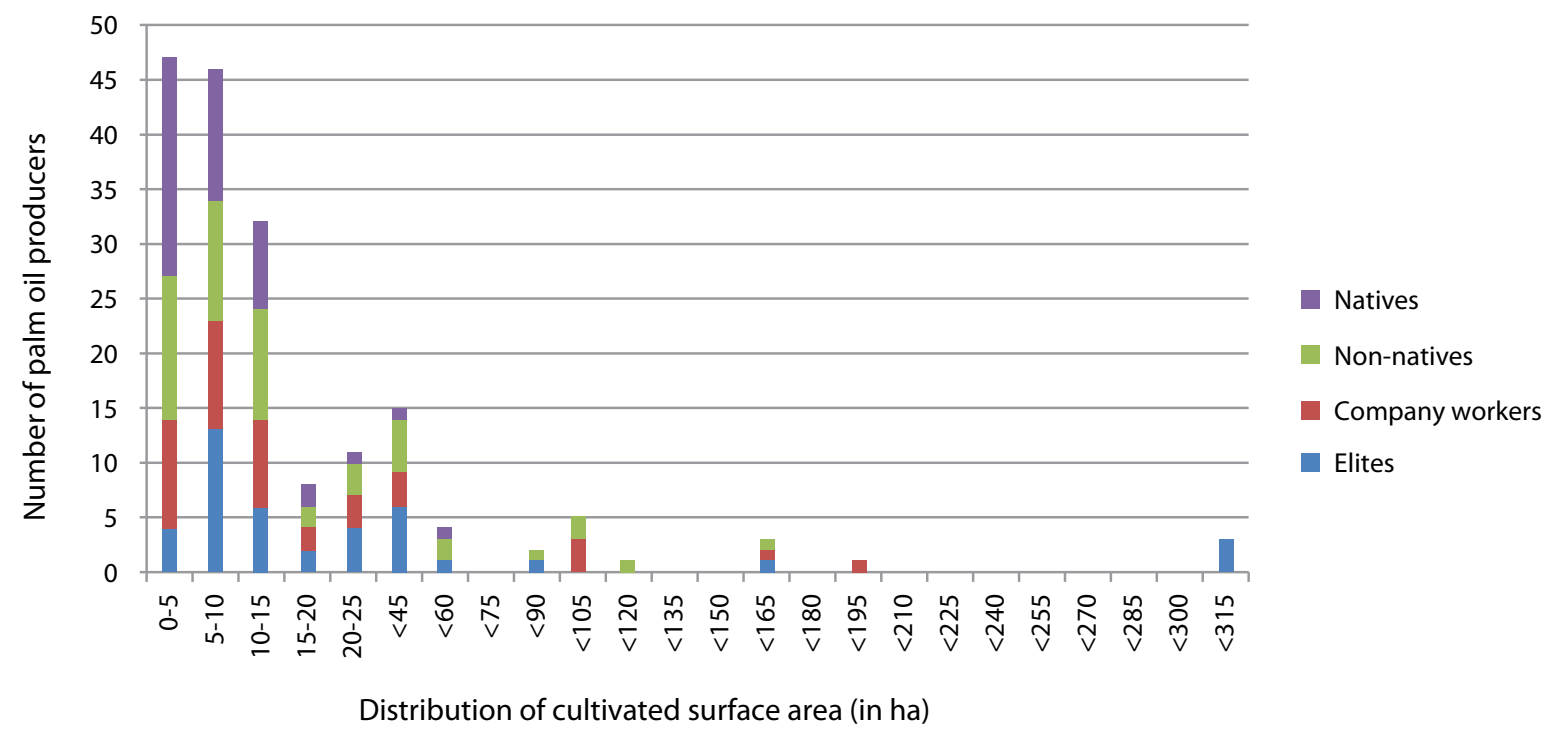

Figure 5. Distribution of areas for different types of palm oil producers. 
of other perennial crops like coffee, cocoa, rubber, etc.).

- Former food-crop land: $19.1 \%$ (this includes areas that were formerly used for the cultivation of annual food crops).

The price for a hectare of land in the major oil palm production basins ranged from 305 to $610 € /$ ha in Mundemba/Lobe, 511 to $762 € /$ ha in Dibombari, 534 to $838 € /$ ha in Eseka and 1143 to $3354 € /$ ha in Muyuka. The respondents further explained that many "bottlenecks" are involved in the attribution of a land title to a piece of land by the government. Concerning the origin of capital for the cultivation of oil palm, $83.6 \%$ of the respondents got their capital through personal savings, $28.8 \%$ through bank loans, $4 \%$ through cooperatives and $3.4 \%$ through government grants.

\subsection{Management of an oil palm plantation}

Apart from the cost incurred to purchase a piece of land, the smallholder needs between 1295 to $1733 €$ to establish and maintain a hectare of oil palm plantation during the first 4 years before the plantation finally enters into production. Some producers, in a move to ensure the quality of planting material and to reduce production costs, create their own nursery after the purchase of certified chitted seeds from research stations. The nursery site must not become waterlogged and should be close to a fast-flowing and deep stream for irrigation. The nursery type could either be a single- or double-stage nursery, with a fence to prevent the encroachment of rodents. With a single-stage nursery, chitted seeds are planted in large polyethylene bags and cared for until maturity in direct sunlight, while a double stage nursery involves the sowing of chitted seeds in small polyethylene bags usually placed in shade and, after 3-4 months, the seedlings are transferred to larger polyethylene bags and then allowed to acclimatize in direct sunlight. Nursery operations include filling of polyethylene bags with soil, sowing seeds, daily watering, weeding, monitoring of pests and diseases, rogueing (removal and discarding of diseased and genetically abnormal seedlings in the nursery), application of inputs (fertilizers, insecticides and fungicides), etc.

Field operations performed during the establishment phase include: forest under-brushing, felling and burning, lining and holing, purchase of oil palm seedlings, transportation of seedlings to planting site, planting, and protection of plants from rodents with the use of either wire mesh, bamboo, or used milk containers. Burning is generally used because it reduces the cost of field establishment and helps to reduce the population of Oryctes beetles during replanting (Jacquemard 2012). Burning helps to mineralize the mass of important leaf litter in a few hours; this is an important source of organic matter for the palms. At the global scale, burning releases carbon into the atmosphere with detrimental effects on climate change.

Field maintenance includes: strip slashing and the eradication of harmful weeds, ring weeding, purchase and application of inputs (fertilizer, fungicide, pesticide, herbicide), ablation of early bunches to foster vegetative growth, harvesting and pruning, collection, and transportation of FFB, as shown in Table 2.

Only $35 \%$ of the respondents claimed to have used certified planting material directly or indirectly from either of the two main research institutions responsible for the production of certified oil palm seeds in the country (Pamol Research Department and IRAD Dibamba). The major agro-industries, as well as intermediaries who buy chitted tenera varieties, raise their plants in nurseries and, at maturity, sell to those in need (seedlings are of doubtful origin and quality). The remaining $65 \%$ had a mixture of both tenera from either the research department in Pamol or IRAD Dibamba, mature seedlings from agro-industries, as well as from intermediaries, and seedlings from their own oil palm plantation. It was difficult to estimate the fraction of land covered by the tenera and native oil palm variety, but what is important is that most palm oil producers were progressively felling the native palms and replacing them with the quality variety. The cost of chitted nuts in the research stations stood at between 0.3 to $0.45 € /$ seed, while a fully grown oil palm seedling sold at between 2.29 to $4.34 €$ depending on the age of the seedling in the nursery. The seeds produced in the various research stations were also of different types: normal seeds and Fusarium-wilt tolerant seeds. Fusarium wilt tolerant seeds are more expensive than the normal seeds (at the Pamol research unit in Lobe it is sold at $0.38 € /$ seed, while at La Dibamba research center, it is sold at $0.45 € /$ seed).

Of the sampled palm oil producers, $68 \%$ of respondents could not afford to apply fertilizers on 
Table 2. Field operational costs for the establishment and upkeep of a hectare of oil palm plantation.

\begin{tabular}{|c|c|c|c|c|c|c|}
\hline Operations & Timing & $\begin{array}{l}\text { Frequency / } \\
\text { year }\end{array}$ & $\begin{array}{c}\text { Operational } \\
\text { cost (in Euros) } \\
\text { Year } 0\end{array}$ & $\begin{array}{c}\text { Operational } \\
\text { cost (in Euros) } \\
\text { Year } 1 \text { and } 2\end{array}$ & $\begin{array}{c}\text { Operational } \\
\text { cost ( in Euros) } \\
\text { Year } 3\end{array}$ & $\begin{array}{c}\text { Operational } \\
\text { cost (in Euros) } \\
\text { Year } 4\end{array}$ \\
\hline $\begin{array}{l}\text { Forest under- } \\
\text { brushing/slashing }\end{array}$ & Nov to Dec & $\begin{array}{l}3 \text { times / year } \\
\text { for young palms }\end{array}$ & 53.36 & 129.58 & 91.47 & 91.47 \\
\hline Felling and burning & Dec to Feb & & 76.22 & 0 & 0 & 0 \\
\hline $\begin{array}{l}\text { Acquisition of } \\
\text { selected seedlings }\end{array}$ & Mar to April & & 381.12 & 0 & 0 & 0 \\
\hline $\begin{array}{l}\text { Acquisition of } \\
\text { wire mesh }\end{array}$ & Mar to April & & 60.98 & 0 & 0 & 0 \\
\hline Various transportation & Mar to April & & 30.49 & 0 & 0 & 0 \\
\hline $\begin{array}{l}\text { Pre-lining, lining and } \\
\text { digging }\end{array}$ & Mar to April & & 45.73 & 0 & 0 & 0 \\
\hline $\begin{array}{l}\text { Planting of seedlings } \\
\text { and protection with } \\
\text { wire mesh }\end{array}$ & April to May & & 30.49 & 22.87 & 0 & 0 \\
\hline $\begin{array}{l}\text { Fertilizer purchase } \\
\text { and application }\end{array}$ & $\begin{array}{l}\text { April- May } \\
\text { \& Sept-Oct }\end{array}$ & Twice a year & 27.44 & 38.11 & 60.98 & 60.98 \\
\hline Circle weeding & $\begin{array}{l}\text { Apr-May } \\
\text { \& Sept-Oct }\end{array}$ & Twice a year & 0 & 45.73 & 32.01 & 45.73 \\
\hline $\begin{array}{l}\text { Harvesting and } \\
\text { transportation of } \\
\text { bunches }\end{array}$ & $\begin{array}{l}\text { All year } \\
\text { round }\end{array}$ & Twice a month & 0 & 0 & 91.47 & 121.96 \\
\hline Total & & & 705.83 & 236.3 & 275.93 & 320.14 \\
\hline
\end{tabular}

Source: 2012 fieldwork

their farms, 30.9\% applied it irregularly and $1.1 \%$ regularly fertilized their land. With respect to the different types of palm oil producers, only $4 \%$ of elites used regular fertilization, whereas none of the other oil palm producers fertilized their land regularly, as shown in Table 3.

Farmers attribute this low rate of fertilizer application to the high cost of fertilizer presently sold in the local market. Fertilizer that used to cost 4.57 to $6.10 €$ $150 \mathrm{~kg}$ during the first oil palm development plan in the late 1970s has risen to 22.87 to $42.69 € / 50$ $\mathrm{kg}$ depending on the brand of fertilizer. Apart from fertilizer, the cost of other inputs like insecticides, fungicides and herbicides has also increased tremendously. Although there are plans to open a fertilizer factory (Ngah 2011), the government has to import fertilizer and other agricultural inputs from other countries, and currently no longer subsidizes the purchase of these agricultural inputs.
The control of weeds represents another cost for the planters during the pre- and early-production period of the plantation. Control measures often need to be intensified at least three times a year, especially when the palms are still young, otherwise the juvenile palms may be ravaged by rodents. As the palms mature, the weeding frequency can be reduced to twice a year. With respect to the sampled palm oil producers, $99.4 \%$ control weeds manually at the pre-production stage of their oil palm plantation, $65.7 \%$ through intercropping with other food crops and $19.7 \%$ through the use of herbicide. Farmers did not stick to a single weed control method and often adopted all three strategies. At early production, $100 \%$ of the sampled farmers manually controlled weeds, while $51.7 \%$ were able to occasionally use herbicides. Most often, the use of these herbicides was limited to the eradication of harmful weeds and ring weeding, and palm oil producers mostly used contact herbicides when their oil palm plantations 
Table 3. Fertilizer application by different types of palm oil producers.

\begin{tabular}{lcccc}
\hline Type of palm oil producers & \multicolumn{2}{c}{ Regularity in fertilizer application (\% respondents) } & \multirow{2}{*}{ Total } \\
\cline { 2 - 4 } & Regular application & Irregular application & No application & \\
\hline Elites $(\mathrm{n}=41)$ & 4.0 & 42.7 & 53.3 & 100 \\
Company workers $(\mathrm{n}=40)$ & 0.0 & 29.1 & 70.9 & 100 \\
Non-natives (Migrants) $(\mathrm{n}=51)$ & 0.0 & 24.5 & 75.5 & 100 \\
Natives $(\mathrm{n}=44)$ & 0.0 & 27.6 & 72.4 & 100 \\
\hline Total (in \%) $(\mathrm{n}=176)$ & $\mathbf{1 . 1}$ & $\mathbf{3 0 . 9}$ & $\mathbf{6 8 . 0}$ & $\mathbf{1 0 0}$ \\
\hline
\end{tabular}

Source: 2012 fieldwork

were still young and systemic herbicides as soon as the oil palms were mature. The shading effect of the fronds of the oil palm trees does not allow intercropping at the production stage. The cropping system adopted at the immature stage by the majority of the palm oil producers also differs from that of agro-industries which is essentially monocropping.

Major pests and diseases identified in the nursery included Cercospora leaf spot, anthracnose and blast, all of fungal origin. Blast is a fungal disease transmitted by the insect vector Recillia mica, which can ravage about $85 \%$ of the nursery seedlings if appropriate control measures (cultural practices and the use of fungicides) are not put in place. Major pests and diseases affecting field palms include Fusarium wilt caused by Fusarium oxysporium, Ganoderma bud rot, which tends to affect palms over 15 years of age, and the leaf miner (Coelaenomenodera minuta uh.), which bores into the mesophyll layer of the leaf thus reducing its photosynthetic ability and invariably leads to low yields. Rodents can also be very harmful especially for juvenile seedlings during the pre-production stage if appropriate control measures are not put in place. Of the sampled palm oil producers, $46.6 \%$ of the farmers reported the incidence and severity of pests and diseases in their oil palm plantation to be insignificant, $49.4 \%$ reported the incidence and severity to be moderate and $2.8 \%$ reported the incidence and severity to be high. Some pests and diseases are endemic to specific oil palm production basins. According to Etta, Plantation Manager, Pamol Lobe (pers. com.), Ganoderma bud rot is endemic to part of the Muyuka palm oil production basin of Ekona town. There is an obvious lack of information on the impact of pests and diseases on the production, most of the respondents considered the effect of pests and diseases to be insignificant, whereas field observations in Mungo palm estate located in Muyuka town showed that some plots were heavily infested with Ganoderma resulting in the death of palms, though no estimate was recorded. According to Forwang, Estate Manager of Mungo palms (pers. com.), apart from the irregular application of fertilizer, which is due to the high cost, the Mungo palm estate is facing serious problems with pests and diseases, with Ganoderma being the most significant.

Farmers responded positively on the availability of some rudimentary working tools like cutlasses, spades, diggers and wheelbarrows in the local market but decry the sharp increase in price as compared to previous years. Quality pruning and harvesting knives (Malaysian knives) with poles were scarce in the local market, and the locally fabricated knives are expensive and not durable, most farmers complained. These locally fabricated knives were sold between 38.11 to $45.73 €$ and, together with the pole, could amount to about 121.96 to $152.45 €$. This has forced some farmers to resort to the use of bamboo poles, which are not useful for very tall palms.

Oil palm planters mostly practice intercropping at the pre-production stage, with the palms regaining their monospecific status at production stage. The choice of quality of planting material, inputs and management practices depends on knowledge, level of information and income status of the different palm oil producers. Care is required in the choice of crops to intercrop with oil palm and the spatial and temporal patterns to be used. Agro-industries generally use certified seedlings and do not intercrop at the pre-production stage, instead seeds of leguminous cover crops (Centrosema, Mucuna, etc.) are broadcast during field establishment. These leguminous cover crops fix atmospheric nitrogen and prevent weeds becoming established in the plantation. The agro-industries apply recommended rates of fertilizer, at least at the pre-production stage 


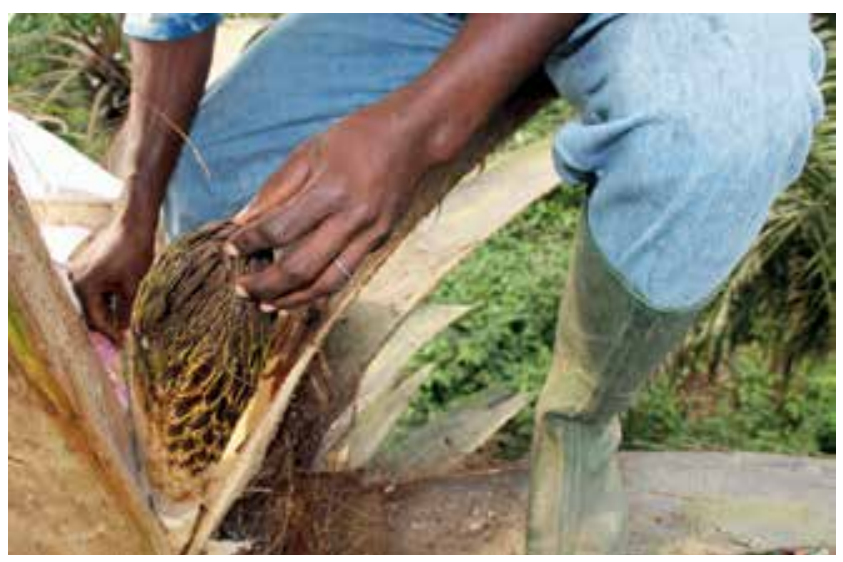

Figure 6. Controlled pollination of the female inflorescence of oil palm in IRAD La Dibamba.

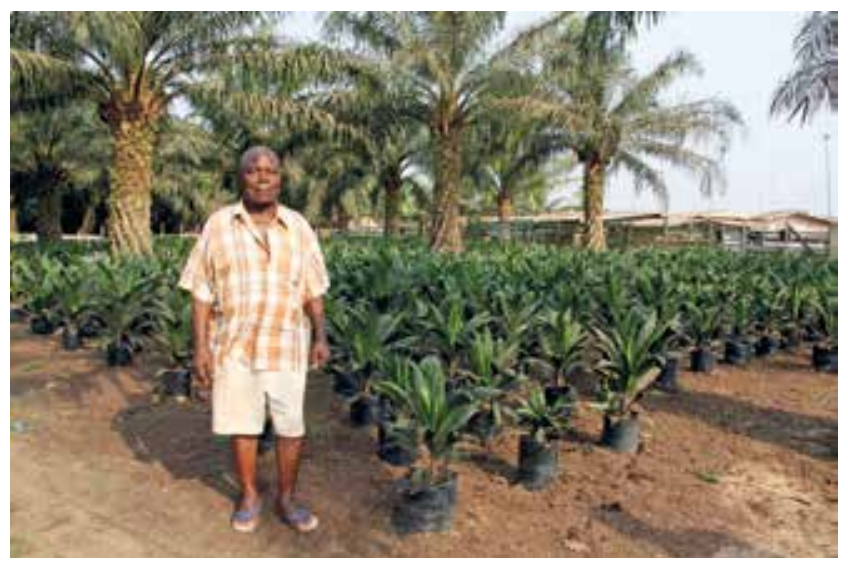

Figure 8. Nursery of an elite palm oil producer.

of the plantation, based on standard recommended doses for the area.

The yields of the palm oil producers range from 3 to 11 tons FFB per hectare per year as the palms enter maturity. The yield range above can be calculated according to the age of the palm, an estimate of the number of bunches harvested each month during the peak- and low-production season, as well as the average bunch weight. Palm oil producers naturally do not keep farm records and thus their yield is mostly based on estimates. The average yield recorded from the field survey for the different types of palm oil producers was as follows:

- Elites: $8.4 \mathrm{t} \mathrm{FFB/ha/yr.}$

- Current/former company workers: $8.1 \mathrm{t} \mathrm{FFB/ha/yr.}$

- Non-native (migrants): 7.3 t FFB/ha/yr.

- Native (villager): 7.0 t FFB/ha/yr.

Elites and company workers registered slightly better yields of $8.4 \mathrm{t}$ and $8.1 \mathrm{t}$, respectively, compared to migrants and natives, which could be due to access

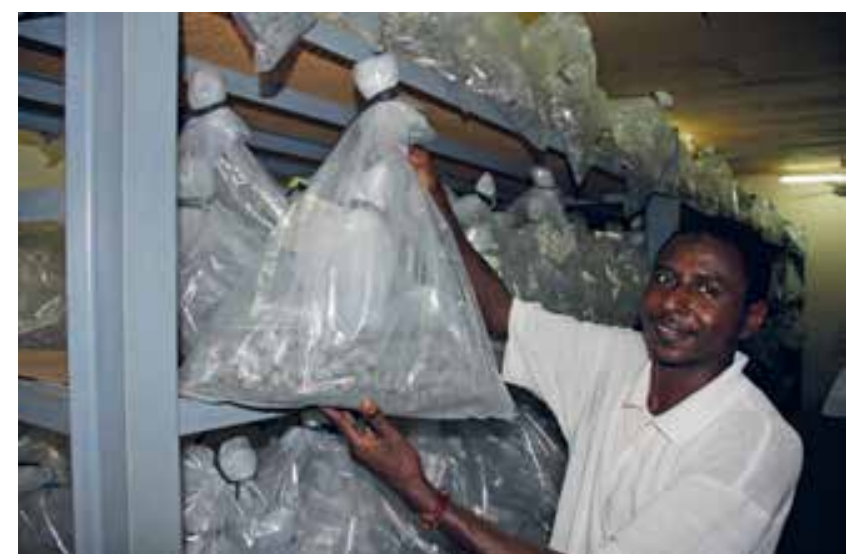

Figure 7. Production of quality seeds at IRAD La Dibamba.

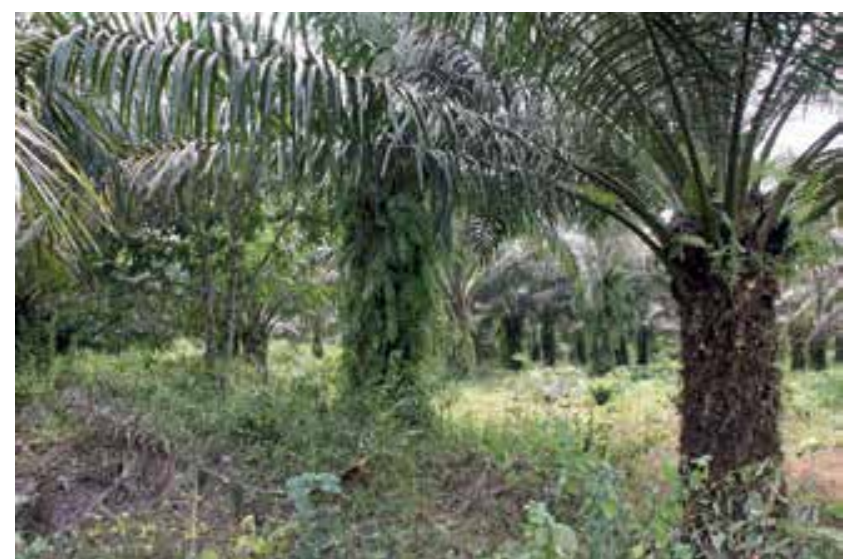

Figure 9. "Smallholder" oil palm plantation in Eseka (Centre Region).

to quality planting materials and better management of the plantation. But the yield difference per type of palm oil producer was not great, probably because of the absence of regular fertilization.

\subsection{Labor}

Regarding labor, $24.2 \%$ of the farmers used family labor, $29.8 \%$ hired native workers, and $94.4 \%$ hired migrant workers from other parts of the country. The total exceeds $100 \%$ as many planters used more than one type of laborer. The northwest followed by the northern regions of the country supply most of the migrant workers found in the non-industrial palm oil sector in the country, while $3.4 \%$ hired foreigners, mostly Nigerians. Nigerians were mostly found in the Southwest region of the country, since this region shares a long border with the Federal Republic of Nigeria. Family labor (which comprises the smallholder, the wife, the children and extended family) is mostly used when the size of the farm is relatively small (0-5 ha) to perform almost all farm 
operations except for the most sensitive, such as harvesting and pruning, which need experienced hired labor if the expertise is not available in the family. As the farm gets bigger, the producer recruits a permanent workforce. Temporary workers are hired occasionally, when the workload on the farm is excessive, to perform specific operations, especially during the peak-production season. Permanent labor is recruited based on aptitude and physical fitness to perform daily operations under the supervision of the grower or farm manager; payment is at the end of each month, with variation in salaries depending on the operations performed. The family may still be there to assist the planter in performing operations like ring weeding, slashing, collecting loose fruits, applying inputs like herbicide and fertilizer, as well as supervision.

Labor poses a serious problem in both the nonindustrial and the agro-industrial oil palm sector as regular recruitment has to be carried out constantly in order to keep the labor force especially if the plantation is located in a very isolated locality. This is partly because the active populations of the plantation locations are not interested in working on these plantations and prefer to move to cities in search of better jobs, or they prefer to carry out other activities in their village. This has led to migration of the labor force, especially from the northwest and northern regions of the country to the southern forest zones where oil palm is cultivated. In the absence of mechanization, most of the operations are performed through the use of manual labor. These operations are tedious and some require a degree of aptitude; most palm oil producers complain about the shortage of labor on their plantations.

With regards to stability of work force, $90.4 \%$ of oil palm growers had a non-permanent work force and $9.6 \%$ had a permanent work force. Only $1.1 \%$ of this permanent work force was enrolled at the National Social Insurance Fund (CNPS) to benefit from social security at retirement. The absence of social security and fluctuation in farm operational costs from one "smallholder" oil palm plantation to the other has resulted in the high mobility of workers amongst these plantations, in the sense that these workers are always ready to move from one farm to the other in quest for a better pay and quicker payment. This is observed amongst both the native and non-native categories of workers.

A total of $41.6 \%$ of the sampled palm oil producers were registered members of a cooperative or common initiative group $(\mathrm{CIG})$, but the bargaining power of most of these groups for quality planting material, inputs like fertilizer and pesticides, as well as the ability to obtain loans from financial institutions was not felt by most of the sampled palm oil producers.

\subsection{Economic results}

In the sample, only $25.6 \%$ of the planters sold their fresh fruit bunches (FFB) exclusively to an industrial mill; $27.3 \%$ either sold their FFB to industrial mills or to artisanal mills depending on the season and amounts harvested; $47.1 \%$ exclusively processed their oil at artisanal mills (personally owned or not). Given that the current price of FFB sold to agro-industries is maintained at 64.03 to $76.22 €$, the quantity sold to industrial mills will largely depend on the size of the plantation, the distance to the industrial mill and the season of production. The amount of artisanal mills, both manual and motorized has increased in recent years, leading to high competition with the industrial mills in the processing of FFB. Despite their low extraction rate $(15 \%)$ compared to that of the nucleus mill (21 to 25\%) (Cheyns and Rafflegeau 2005; Ngom 2011), they are a force to reckon with in terms of the value added to the FFB and the additional income to the smallholder. For example, a ton of FFB sold for $73.18 €$ to Socapalm, $64.03 €$ to Pamol and 76.22 € to CDC could be processed by a smallholder in an artisanal mill to yield between 150-200 L of CPO. The retail price of CPO ranges from 0.76 to $1.22 € / \mathrm{L}$ during peak and low season respectively, in the Muyuka zone. A woman (intermediary) can incur $121.2 €$ total expenditure (FFB purchase, transportation, labor and milling charge) for a ton of processed FFB during the lowproduction season and mills $150 \mathrm{~L}$. If she happens to retail during this period at $1.22 € / \mathrm{L}$, she is able to make a $182.94 €$ gross profit, or a net profit of 61.74 $€$ from the purchase of a ton of FFB. Meanwhile, the oil palm grower who also performs the same activity in an artisanal mill will earn a lot more profit 69.36 to $145.59 € /$ ton FFB than one who decides to sell his FFB to any of the aforementioned companies, as shown in Table 4. This explains why most palm oil producers prefer to process their FFB in an artisanal mill especially during the low-production season. Most FFB processors do not sell their CPO when prices drop, they prefer to keep it and sell when market prices are good. The long shelf life (the period before the oil gets rancid) of 6 months or more, due to the fact that it is solid at room temperature, facilitates this. The shelf life for palm oil is reduced when it contains moisture, dirt and more than 3\% free fatty acids. 
Table 4. The variable cost incurred for the artisanal processing of a ton of oil palm FFB.

\begin{tabular}{|c|c|c|c|}
\hline \multicolumn{2}{|c|}{ Operations } & $\begin{array}{l}\text { Cost at peak season } \\
\text { (in } € / \mathrm{t} \mathrm{FFB))}\end{array}$ & $\begin{array}{l}\text { Cost at low season } \\
\text { (in } € / \mathrm{t} \text { FFB ) }\end{array}$ \\
\hline \multicolumn{2}{|c|}{ FFB purchase } & $61 € / \mathrm{t}$ & $76 € / \mathrm{t}$ \\
\hline \multicolumn{2}{|c|}{ Transportation } & 11 to $18.1 € / \mathrm{t}$ & 11 to $18.1 € / \mathrm{t}$ \\
\hline \multicolumn{2}{|c|}{ Labor charge } & $2.3 \times 5$ drums $=11.5 € / \mathrm{t}$ & $2.3 \times 5$ drums $=11.5 € / \mathrm{t}$ \\
\hline \multicolumn{2}{|c|}{ Milling charge } & $3.04 \times 5$ drums $=15.2 € / \mathrm{t}$ & $3.04 \times 5$ drums $=15.2 € / \mathrm{t}$ \\
\hline \multicolumn{2}{|c|}{ Total expenditure } & 98.2 to $106 € / \mathrm{t}$ & 114 to $121.2 € / \mathrm{t}$ \\
\hline \multicolumn{2}{|c|}{ Price of palm oil/Liter } & $0.76 € / L$ red oil & $1.22 € / L$ red oil \\
\hline \multicolumn{2}{|c|}{ Gross profit } & $114.4 € / t$ FFB & $183 € / \mathrm{t} \mathrm{FFB}$ \\
\hline \multirow[t]{2}{*}{ Net profit } & Intermediary & 8.4 to $16.0 € / \mathrm{t} F F B$ & 61.7 to $69.4 € / \mathrm{t}$ FFB \\
\hline & Palm oil producer & 69.4 to $77 € / \mathrm{t} F F B$ & 138 to $146 € / t$ FFB \\
\hline
\end{tabular}

Source: 2012 fieldwork

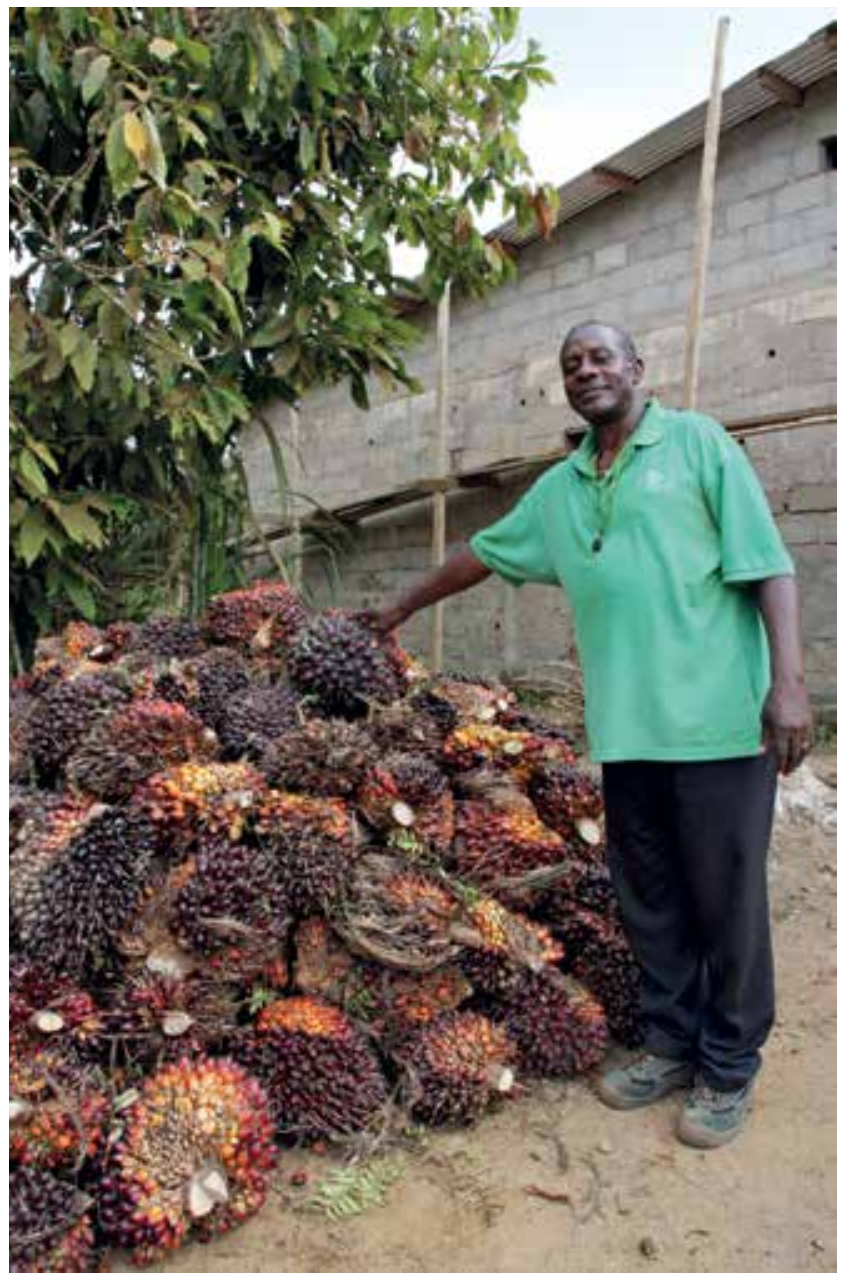

Figure 10. Harvested FFB ready for artisanal milling.

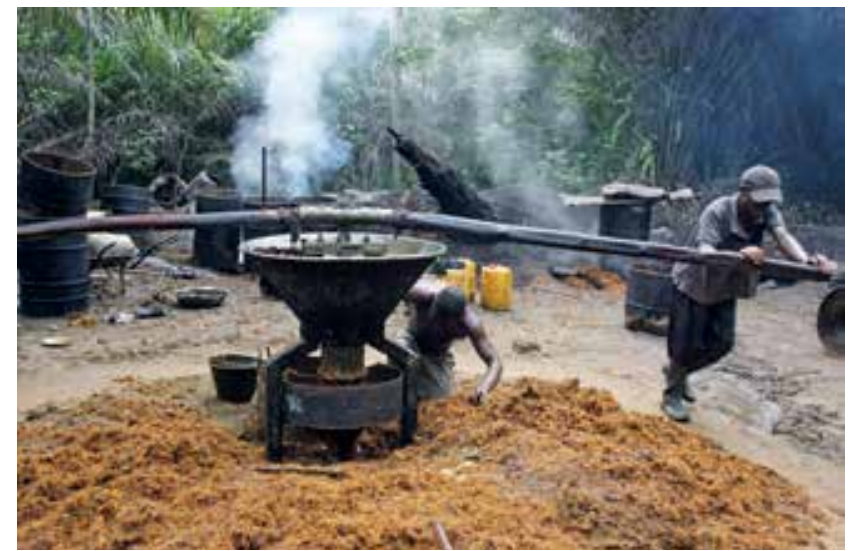

Figure 11. Milling of boiled fruits to produce crude palm oil.

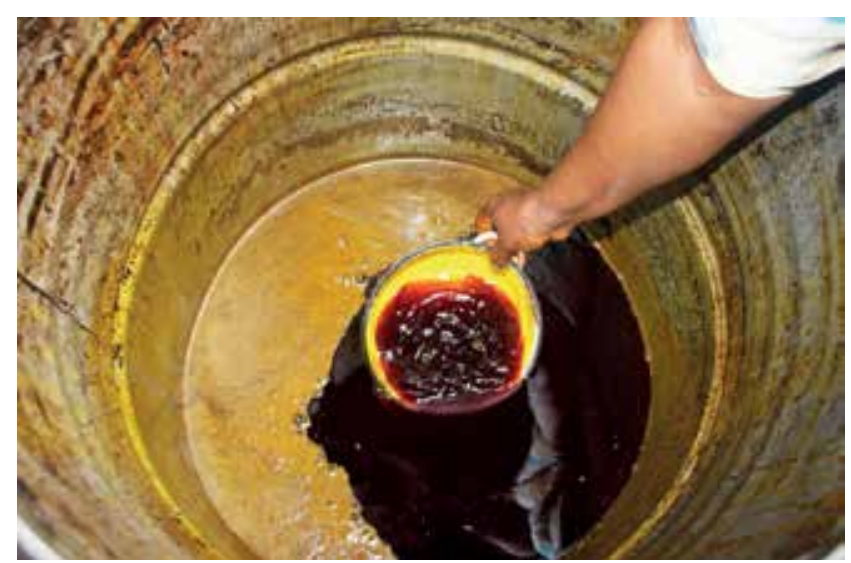

Figure 12. Red palm oil ready for consumption after clarification. 
Table 5. Revenue derived from the sale of FFB and red palm oil (in Euros).

\begin{tabular}{cccccccc}
\hline Year & $\begin{array}{c}\text { Estimated } \\
\text { yield } \\
\text { (t/ha/yr) }\end{array}$ & $\begin{array}{c}\text { Field mang't } \\
\text { Cost }\end{array}$ & $\begin{array}{c}\text { Revenue } \\
\text { (FFB Sale) }\end{array}$ & $\begin{array}{c}\text { Cumulative } \\
\text { (R-E) }\end{array}$ & $\begin{array}{c}\text { Field mang't } \\
+ \text { PC }\end{array}$ & $\begin{array}{c}\text { Revenue (oil } \\
\text { sale) }\end{array}$ & $\begin{array}{c}\text { Cumulative } \\
\text { (R-E) }\end{array}$ \\
\hline 0 & 0 & 705.84 & 0 & -705.84 & 705.84 & 0 & -705.84 \\
1 & 0 & 236.30 & 0 & -942.14 & 236.30 & 0 & -942.14 \\
2 & 0 & 236.30 & 0 & -1178.43 & 236.30 & 0 & -1178.43 \\
3 & 0 & 275.93 & 0 & -1454.37 & 275.93 & 0 & -1454.37 \\
4 & 4 & 320.14 & 292.70 & -1481.81 & 500.03 & 582.36 & -1372.04 \\
5 & 6 & 365.88 & 439.05 & -1408.63 & 635.71 & 873.53 & -1134.22 \\
6 & 8 & 396.37 & 585.41 & -1219.59 & 756.15 & 1164.71 & -725.66 \\
7 & 9 & 411.61 & 658.58 & -1030.56 & 816.37 & 1310.30 & -231.72 \\
8 & 10 & 426.86 & 731.76 & -725.66 & 876.58 & 1455.89 & 347.58 \\
9 & 10 & 426.86 & 731.76 & -420.76 & 876.58 & 1455.89 & 926.89 \\
10 & 10 & 426.86 & 731.76 & -115.86 & 876.58 & 1455.89 & 1506.20 \\
11 & 10 & 426.86 & 731.76 & 189.04 & 876.58 & 1455.89 & 2085.51 \\
12 & 10 & 426.86 & 731.76 & 493.94 & 876.58 & 1455.89 & 2664.81 \\
13 & 10 & 426.86 & 731.76 & 798.83 & 876.58 & 1455.89 & 3244.12 \\
14 & 10 & 426.86 & 731.76 & 1103.73 & 876.58 & 1455.89 & 3823.43 \\
15 & 10 & 426.86 & 731.76 & 1408.63 & 876.58 & 1455.89 & 4402.73 \\
\hline
\end{tabular}

Price per ton FFB sold to Agro-industry $=73.18 €$; processing cost $(\mathrm{PC}) /$ ton $\mathrm{FFB}=44.97 €$.

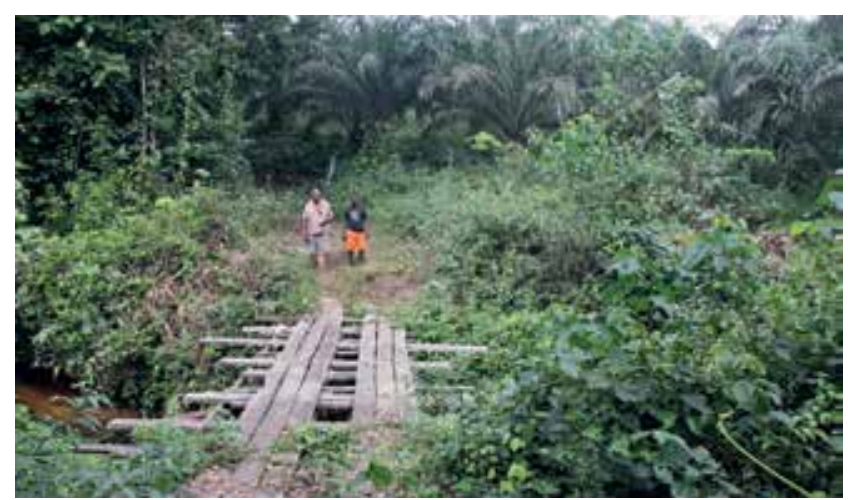

Figure 13. Makeshift bridge leading to a smallholder oil palm plantation.

Table 5 shows that palm oil producers who harvest their FFB and process it in an artisanal mill are able to register a net positive revenue in the eighth year after deducting all costs and also make a higher income, while their counterparts who supply their FFB to the nucleus mill are able to register a net positive revenue in the 11 th year after deducting all costs incurred, and have a comparatively lower income.

\subsection{Future plans for palm oil producers}

At an individual level, some palm oil producers see the need to carry out further expansion of their farms, the replanting of old palms of age $>25-30$ years, as well as the eradication and replacement of the local breed (pisifera and dura varieties). Some also see the need to equip their plantation with an automated mill and to purchase a vehicle/tractor, mainly for the purpose of transportation. They also enumerate problems like the bad state of farm-tomarket roads especially during the peak production season, which partly falls during the rainy season, the high cost of inputs, high cost of planting material, fluctuation in the market price for FFB and CPO, high cost of labor, and absence of subsidy from the state. Most farmers sampled had mixed feelings about the future of the non-industrial palm oil industry but were optimistic that if they could work in synergy with the state and agro-industrial companies in order to ameliorate some of their present difficulties, then the "smallholder" oil palm sector could be a potential force to reckon with in terms of income generation through direct and indirect employment and poverty alleviation, especially in rural settings. 


\section{Discussion}

\subsection{Strengths and weaknesses of the sector}

Agriculture forms the backbone of Cameroon's economy, and $70 \%$ of the population depends on agriculture and pastoral activities for their livelihood (World Bank 2012). The non-industrial palm oil sector creates direct and indirect job opportunities and generates income for people of all age groups and social status, thus participating in poverty alleviation. Most palm oil producers have the basic knowledge to establish an oil palm plantation, regardless of their level of education, though to some extent they still need to seek the advice of agricultural experts. What usually poses a problem is the financial capital needed to invest in oil palm cultivation, as very few palm oil producers are able to afford such a huge amount (1 295.82 to $1733.35 € /$ ha), excluding the price for the purchase of a hectare of land. In addition to this, very few institutions are willing to lend money at very low interest rates to palm oil producers allowing a grace period of 3-4 years for the palms to enter production (Bakoumé et al. 2002; Rafflegeau 2008). The absence of a farmers' bank (specialized in agricultural investment) to lend money to palm oil producers is a major problem, though the Head of State recently promised the creation of a bank that will charter for the needs of the farmers (Ngah 2011). According to Dimelu and Anyaiwe (2011) the bulk capital utilized by palm oil producers comes from personal savings or informal sources, and this capital is grossly inadequate for improved and sustained production. International and domestic banks provide large loans to estate plantations, but do not target oil palm growers. The lack of an appropriate policy by the government also reveals the stagnation in the sector's production. The aging population in the sector is a concern. Oil palm should be made more attractive to the youth through provision of land, incentives and the formulation of better policies that will help to reduce the rural exodus.

Fonjong (2004) argues that the fight against poverty and the drive towards food sufficiency by the state remains a fallacy given the collapsing state of agropastoral infrastructure in the country. The cropping system adopted by most palm oil producers, which involves the intercropping of oil palm together with some food and cash crops during the initial stages of the plantations helps to minimize environmental change induced by the artificial monospecific system, prevents soil erosion, optimizes the utilization of different soil nutrients and enhances food security (Tonye et al. 2004; Bakoumé 2006). But this intercropping does not last long as the farm finally recovers its monospecific status at production stage. Worse still, if a better intercropping method is not implemented (that considers the crops to intercrop with oil palm, temporal and spatial design in planting, as well as best management practices), this will have a negative effect on the yield of oil palm at the production stage.

The sector benefits from the presence of a domestic and sub-regional market, though with some fluctuations in the market price for palm oil depending on the season of production. In contrast to the price of CPO from agro-industries which is regulated by the government at $0.69 € / \mathrm{Kg}$ and the distribution to downstream industries, no regulation is put on CPO from the non-industrial palm oil sector and this is of advantage to the oil palm grower because during low-production season, the price can increase to 1.22 and even $1.98 € / \mathrm{L}$, while at peakproduction season, the price can fall to $0.76 €$. The choice of the time of sale and customer is important for the oil palm grower.

According to Bakoumé (2006), palm oil producers need assistance from the state and have to organize themselves into active groups/cooperatives to overcome many constraints (lack of access to capital, quality planting material, inputs, transportation difficulties, etc.) that limit oil palm profitability, and thus their contribution to increasing national production. At present, the country does not have a fertilizer manufacturing plant, thus there is heavy reliance on imports. Most planters record very low yields in their plantations. Lebailly and Tentchou (2009) and Ngom (2011) reported low yields in the smallholder oil palm sector. Rafflegeau et al. (2010) propose a range of $2-14 \mathrm{t} / \mathrm{ha} / \mathrm{y}$ as the yield for the non-industrial palm oil sector depending on the age and management methods. The low yield is also partly attributed to the 4 months of drought experienced in the course of the year 
(Ngoko et al., 2004). Hirsch (1995), Donough et al. (2009) and Jannot (2010) reiterate the need for better management practices (crop recovery, quality planting material, fertilizer application, ground cover, water management, pest and disease control, canopy management, general management) and the use of "already cleared land" as ways to improve yield and avoiding further encroachment into the forest. Durand-Gasselin et al. (2010) advise plant breeders to focus on yield improvement, improvement to the life cycle of the plantation and selection for resistance to diseases as factors that will improve the sustainability of the crop. Caliman et al. (1994) stress the need for precise, accurate and reliable laboratory analysis of foliar samples as a prerequisite for better fertilizer use.

That notwithstanding, palm oil producers can still realize better profit margins especially when value is added to their FFB. Fournier et al. (2000) show that artisanal milling of FFB is one of the most profitable activities for Beninese women. According to Feintrenie (2012), the artisanal transformation of FFB also provides an opportunity of income for widows and single women, who have poor access to land.

Previous studies by Etta et al. (2007) focused on yield improvement through the utilization of empty fruit bunches (EFB) as a source of organic manure, supplemented with reduced rates of inorganic fertilizer for field palms, which resulted in significant yield improvement for as low as 30 tons of EFB applied to lateritic sandy soils. However, limitations came from the quantity of EFB that is produced per ton of FFB with $22-25 \% \mathrm{EFB} /$ ton of FFB (Rosenani et al. 1996), as well as logistics and transportation difficulties that may arise depending on the distance of the plantation from the mill.

The relationship between palm oil producers and the agro-industries has changed since the first oil palm development plan in the late 1970s. Today, because of the advent of artisanal mills and the profit margin obtained from adding value to the crop, very few oil palm planters are dependent on the agro-industries, coupled with the fact that these companies offer very little assistance to these oil palm planters. This is supported by Hirsch (2000), who showed that oil palm growers prefer to process part or all of their FFB in order to make more profit. Under fair partnerships between oil palm growers and companies, oil palm could be of more benefit to planters (Feintrenie et al. 2010; Skurtis et al. 2010). Carrère (2010) acknowledges the non-industrial palm oil sector as a potential source of income, employment and development especially in rural settings.

Some palm oil producers have customary claims to land, and there is land available that is suitable for the cultivation of the crop. In recent years, with the increase in pressure on arable land suitable for oil palm cultivation, land prices have steadily increased, thus forcing people to go further into the forest where they can get cheaper land. At present, the non-industrial palm oil sector is thought to pose little threat to the primary forest, but still very little regulation has been put in place by the government to mitigate the effect that "smallholder" oil palm development might have on the environment. A majority of their holdings are located in areas that were formerly occupied by secondary forest, in contrast to agro-industries, which usually acquire huge expanses of land, mostly primary forest, for oil palm cultivation.

\subsection{Learning from other countries}

The FONADER scheme is very similar to the nucleus estate and smallholders scheme (NES) developed in Southeast Asia and more specifically in Indonesia. The same criticisms are made on the bad treatment reserved to migrant workers living in the estates or working for sub-contracted companies, and on the smallholders in partnerships who are often considered as captive producers assuming all the risks related to agricultural production (Elong, 2003; Carrère, 2010; Feintrenie et al., 2010). In Indonesia, there is no traditional knowledge of artisanal oil production, thus oil palm growers are dependent on industrial mills to buy and process their FFB, which makes the main difference with Cameroon (Feintrenie, 2012a). In the regions where several palm oil industrial mills are present, FFB producers and middlemen can negotiate FFB price at mill gate, benefiting from the competition among mills. On the opposite, in regions where one oil palm company has a monopoly for buying FFB, the price is decided by the mill, even though based on a formula taking into account the $\mathrm{CPO}$ price on the world market and validated by the provincial authorities. In the Indonesian NES model, credits proposed to contracted-smallholders are paid back through a direct withdrawal by the company on the payment of FFB. If under a mill monopoly there is no chance for a smallholder to escape from his debt, although in situations where there are several mills, this risk is limited by the organization of contracted smallholders as cooperatives closely 
working with the company. On the opposite, the presence of the artisanal palm oil sector and the domestic oil production in Cameroon opens a window for contracted-farmers not to respect their contract, and sell their production out of the mill without paying back their debt (Feintrenie, 2012a). Another pattern of industry-smallholders partnership is being developed in Colombia under the name of "Alliances". Alliances are based on a joint-venture between an oil palm company which builds a mill and owns an industrial plantation, and individuals who join the partnership with their own land and become shareholder of the mill in proportion to the surface of their land. The involved company benefits from both some financial help under favorable conditions under the supervision of the government and from a secure supply of FFB. The individual FFB producers benefit from technical assistance, access to credit, access to inputs at better prices, and the organized collection of FFB at plantation gate (FEDEPALMA, 2010). In this business model, the joint-venture covers both the plantation and the mill, which creates an interest for the contracted producer in the economic results of the mill, and thus a motivation not to sell his/her FFB to another mill. This model opens new areas of interest in the search for an adequate business model for Cameroon's oil palm development.

\subsection{Elites' role in oil palm development}

It would be unfair to reduce the involvement of elites in agriculture to that of "grabbing" land. At a time when the state's involvement in the agricultural sector is almost insignificant, elites are virtually the only driver of agricultural development in Cameroon. Following the recurrent failure of major projects and agricultural development in Cameroon in the 1980s, the implementation of the Structural Adjustment Programme in 1989 resulted in the withdrawal of state supervision of peasantry. Withdrawal, concomitant with the fall in the prices of major agricultural exports led to the virtual disappearance of sources of rural finance and consequently the contraction of economic activity. Hopes for the development of microfinance proved exaggerated, and tontines remained the only financial instrument available to rural households. Unfortunately, the amounts redistributed by tontines are too weak to support agricultural development projects, and are usually reserved for the financing of social and cultural activities.

As a result, the only really active form of financing in rural areas to date is that provided by the elites.
Of course this funding is dedicated to activities initiated and controlled by the elites. But the supply of money for the purchase of land is redistributed to landowners of the village, and the establishment of plantations generates significant employment opportunities for the poorest households in the village. Unfortunately, it is clear that the money raised by the sale of land is seldom used to finance productive investment and employment opportunities are mainly captured by migrants. Should we then prohibit or discourage investment by elites? In this case, the elites are not responsible for the misuse of money from the sale of land by the villagers. Clearly, the problem that is facing the rural poor in Cameroon comes less from elites than from the absence of alternative sources of funding for agricultural development. Elites merely fill a vacuum, and it is feared that in their absence the situation of the rural population will be even more precarious.

The recent interest of large oil palm companies from Southeast Asian countries in the Congo Basin and particularly in Cameroon could be a blessing or a curse for the village plantation sector. If the state allows these companies to settle with the agro-industrial classic model, small farmers, villagers and elites will be quickly marginalized because they are unable to compete with more efficient agro-industries. On the other hand, if the state determines the land granted to big companies with the integration of a large number of small planters along the lines of a nucleus estate owned by the agro-industry and plasma plantations owned by smallholders (Nucleus Estate and smallholder schemes) and Alliances adapted from the Columbian model there will be the potential for poverty reduction from oil palm (Levang and Nkongho 2012).

\subsection{Social and environmental impact of large-scale oil palm development}

Oil palm development offers direct and indirect employment opportunities to the local population as well as income through the payment of taxes to the state (Hoyle and Levang 2012). As opposed to "smallholders", most agro-industries prefer to utilize the natural forest for the development of oil palm plantations. This is advantageous in the sense that they can easily get access to a big block of concession, which leads to reduction in management cost as opposed to concessions scattered in space, coupled with increased soil fertility status after the natural forest is felled down. If governance measures are weak 
and coupled with corrupt practices, these companies enforce their deals with the government, thereby undermining the local and indigenous population who lay customary claims to land. The absence of free prior and informed consent could be a potential source of conflict between local populations and agro-industries, since land is expropriated without prior consultation or any meaningful compensation (Freudenthal et al. 2012). The natural forest is also a source of livelihood to the local population who rely on it for the harvesting of non-timber forest products, fuel wood, medicinal plants and bush meat. When the agro-industries finally becomes established, the social infrastructure development such as electricity, pipe-borne water, housing, hospitals, etc., are often limited to estate employees. As such, it is very common to see a well-established company with a "sea" of surrounding villages living in abject poverty.

In contrast, the natural forest is home to a rich biodiversity of different species of plants and animals (Nguiffo and Schwartz 2012; Pledran 2012; Meijaard and Sheil 2013) and as such the utilization of this ecosystem for oil palm development if care is not taken could lead to deforestation, habitat destruction, habitat fragmentation and the destruction of keystone species. According to Sayer et al. (2012), when oil palm replaces the natural forest, it takes about 75-93 years for carbon sequestration gains to be recorded, compared to less than 10 years for grasslands and up to 600 years for peat forest. If care is not taken untreated waste from the mills, e.g. POME (palm oil mill effluent) with a high percentage of methane, together with runoff from herbicides, pesticides and fertilizers could enter water bodies leading to pollution/eutrophication.

It is against this backdrop that some environmental and social NGOs have stressed the need for the utilization of "already cleared land" for the development of oil palm plantations (Greenpeace 2013). "Already cleared land" could be grassland, fallow land, food-crop land and, to an extent, secondary forest. In Cameroon, for example, the grassland regions are in deficit in the amount of rainfall for oil palm cultivation; here, there is need for the development of drought-tolerant varieties. Fallow land, food-crop land and secondary forest are in the hands of the local population and these "already cleared land" are not continuous in their spatial distribution. Here oil palm smallholdings can be encouraged. Good partnership between incoming companies or already established ones and local population/palm oil producers respectively, could be mutually beneficial for both parties, since it will help in poverty reduction of the local population, reduce social tension between the locals and incoming agro-industries, and will also lead to a reduction in deforestation rates. There is also the need for the strict adherence to the principles and criteria of RSPO (Round Table for Sustainable Palm Oil), as a means of ensuring both environmental and social sustainability and to benefit from future market for CPO (Greenpeace 2013). 


\section{Conclusion}

This study exposes the strengths and weaknesses faced by different types of palm oil producers. Some of the strengths possessed by the different palm oil producers include: posing little threat to the primary forest; artisanal mills, despite their low extraction rate, fetch better income; availability of a domestic and sub-regional market for the sale of palm oil; availability of abundant already cleared land which could easily be used by the different palm oil producers; basic knowledge on oil palm cultivation, though this knowledge may differ according to the type of producer.

The weaknesses exposed by the study include: the fact that none of the palm oil producers are presently in partnership with the agro-industries; very low yields partly attributed to the high cost of inputs; high cost of quality planting materials; low extraction rate of artisanal mills; absence of social security for the labor force; bad state of the roads leading to most of the oil palm plantations, resulting in high transportation cost and making transportation of FFB almost impossible; rudimentary farming tools; and land grabbing for oil palm development by Elites.

There is a clear need for a government policy that will address at least some of the weaknesses mentioned above and that will be able to meet the poverty reduction strategy plan put in place by the government of Cameroon by 2035, without jeopardizing the environment. It highlights the need for an effective partnership between the palm oil producers sector, the agro-industries and research institutions, and the need for farm inputs to be subsidized. Innovative research findings on ways to improve the yield and extraction rates/quality control measures of these artisanal mills are also required. There is also a need to maximize the utilization of oil palm by-products. The gazetting and utilization of "already cleared land" for oil palm cultivation is necessary to limit encroachment into the primary forest. There is also a need for further research into various intercropping models at pre-production and production stages that do not negatively affect the yield of the oil palm. It is against this backdrop that "the national strategy for the development of a sustainable oil palm sector in Cameroon" was created by Ministry of Agriculture and Rural development decision No. 00250/CAB/MINADER/29 on July 2013, under the umbrella of MINADER, with the involvement of other key ministries and research institutions, including the Center for International Forestry Research (CIFOR). The objective is to look at ways of improving the productivity of oil palm, putting in place sustainable development procedures that take into account the social, economic and environmental realities, as well as transparency in legal and institutional frameworks geared towards the acquisition of permits for oil palm development. 


\section{References}

Bakoumé C. 2006. Sustainable development of oil palm in Africa: smallholder sector. International Planters Conference.

Bakoumé C, Jannot C, Rafflegeau S, Ndigui B and Weise S. 2002. Etudes complémentaires sur la relance des filières hévéa et palmier à huile. Yaoundé, IRAD, CIRAD, IITA, FAO.

Caliman JP, Daniel C and Tailliez B. 1994. La nutrition minérale du palmier à huile. Plantations, recherche, développement, 1( 3):36-54.

Carrère R. 2010. Le Palmier à huile en Afrique. Le passé, le présent et le futur. Mouvement Mondial pour les Forêts Tropicales World Rainforest Movement 69p.

Cheyns E and Rafflegeau S. 2005. Family agriculture and the sustainable development issue: possible approaches from the African oil palm sector. The example of Ivory Coast and Cameroon. $O C L$, 12(2):111-20.

Dimelu MU and Anyaiwe V 2011. Priorities in smallholder oil palm producers in Ika Local Government Area of Delta State: Implication for agricultural extension service in Nigeria. World Journal of Agricultural Sciences 7(2):117-23.

Donough CR, Witt C and Fairhurst TH. 2009. Yield intensification in oil palm plantations through best management practice. Better Crops, 93(1):12-14.

Durand-Gasselin T, Blangy L, Picasso C, De Franqueville H, Breton F, Amblard P, Cochard B and Nouy B. 2010. Sélection du palmier à huile pour une huile de palme durable et responsabilité sociale. OCL 17(6):385-92.

Elong JB. 2003. Les plantations villageoises de palmier à huile de la Socapalm dans le basMoungo (Cameroun): un projet mal integré aux préoccupations des paysans. Les Cahiers d'OutreMer 224, October-December.

Etta CE, Nkongho RN, Timti IN and Nebane CN. 2007. The effect of empty bunch mulching applied as organic manure on the yield of oil palms planted on lateritic sandy soils of Pamol Ndian Estate, Cameroon. Proceedings of the PIPOC 2007 International Palm Oil Congress (Agriculture, Biotechnology \& Sustainability). 625-37.

FAO (2000) Forest Resource Assessment. www.cbd. int/forest/definations.shtml
FEDEPALMA-Alianza SNV-USAID/programa MIDAS. 2010. De las alianzas productivas a los negocios inclusivos. Guía de mejores prácticas para la implementación de negocios inclusivos en palma de aceite, $24 \mathrm{p}$.

Feintrenie L. 2012. Oil palm in Cameroon: risks and opportunities. Nature and Faune 6(2): 23-27.

Feintrenie L and Rafflegeau S 2012. Oil palm development: risk and opportunities based on lessons learnt from Cameroon and Indonesia. XVII International Oil Palm Conference 2012, September 25-28. Cartagena, Colombia.

Feintrenie L, Chong WK and Levang P. 2010. Why do farmers prefer oil palm? Lessons learnt from Bungo District, Indonesia. Small-scale Forestry 9:379-96.

Fonjong IN. 2004. Changing fortunes of government policies and its implications on the application of agricultural innovations in Cameroon. Nordic Journal of African Studies 13(1):13-29.

Fournier S, Adje I and Okounlola-Biaoua. 2000. Filière huile de palme au Bénin : une dynamique essentiellement artisanale. OCL 7(2):175-81.

Freudenthal E, Lomax T and Messe V. 2012. The Biopalm Project: A case study in the Département of Océan, Cameroun. Conflict of consent? The palm oil sector at crossroads. UK, Forest Peoples Programme.

Greenpeace 2013. Herakles Farms au Cameroun: Contre-exemple pour l'huile de palme. Washington DC, Greenpeace USA.

Hirsch R. 1995. Le Palmier à huile en Afrique : La nécessaire relance. Montpellier-France, Plantation, Recherche, Développement.19-26.

Hirsch R. 2000. Dynamique récente des plantations individuelles de palmier à huile au Cameroon. OCL 7(2):172-74.

Hornus P, Kamga F and Chaillard C. 1987. Agronomic research and the development of oil palm cultivation in Cameroon. Oleagineux 42(8-9):313-15.

Hoyle D and Levang P. 2012. Oil palm Development in Cameroon. An ad hoc working paper, Yaoundé, WWF, IRD and CIFOR.

Jacquemard JC. 2012. Le palmier à huile. Montpellier-France, Editions Quae, CTA, Presses agronomiques de Gembloux. 
Jannot C. 2010. Emplois, économie, environment: le développement de la filière palmier à huile en Côte-d'Ivoire. OCL 17(6):393-99.

Konings P. 1986. L'Etat, l'agro-industrie et la paysannerie au Cameroun. Politique Africaine 22:120-37.

Lebailly P and Tentchou J. (2009) Etude sur la filière porteuse d'emploi palmier à huile. Final report. Yaoundé : OIT.

Levang P and Nkongho RN 2012. Elites et accaparement des terres au Cameroun: L'exemple du palmier à huile. Enjeux 47-48:67-74.

Mathew JJ, Yong KK and Nurulnahar BE. 2007. Preliminary investigation on biodiversity and its ecosystem in oil palm plantation. Proceedings of Agriculture, Biotechnology and Sustainability Conference 2:1112-58.

Meijaard E and Sheil D. 2013. Oil-palm plantations in the context of biodiversity conservation. In Levin SA (ed.) Encyclopedia of Biodiversity, Volume 2, second edition. Waltham, MA: Academic Press. 600-612.

Ngah GF. 2011. Ebolowa Agro-pastoral show: revival of the great national agricultural policy. Yaoundé, Services du Premier Ministre du Cameroun.

Ngambi JR, Mbouhnoum PAE and Ndjogui TE. 2011. Elite Urbaine, Elaeiculture et Développement Endogène de L'arrondissement de Ngog- Mapubi dans le Nyong-Et-Kelle, Région du Centre (Cameroun). In Elong JG (ed.) L'élite urbaine dans l'espace agricole africain. Paris : L'Harmattan. 211-24.

Ngando EGF, Mpondo MEA, Dikotto EEL and Koona P. 2011. Assessment of the quality of crude palm oil from smallholders in Cameroon. Journal of Stored Products and Postharvest Research 2(3):52-58.

Ngoko Z, Bakoumé C, Djoukeng V, Tchamo P, Imele B and Adon B. 2004. Factors affecting smallholder oil palm production in the Western highlands of Cameroon. The Planter 80(938):299-306.

Ngom E. 2011. Oil palm in Cameroon.

Communication at the event 'Sharing what works in sustainable and equitable oil palm development'. Bogor, Indonesia: CIFOR. 21-27.

Nguiffo $S$ and Schwartz B. 2012. Herakles 13th labour? www.forestpeoples.org

Obam FM and Tchonang Goudjou B. 2011. Plantations de Palmiers à Huile des Elites Urbaines, Mutations Sociospatiales et Effets
D'entrainement dans la Région du Sud (Cameroun). In Elong JG (ed.) L'élite urbaine dans l'espace agricole africain. Paris: L'Harmattan. 200-209

Obam FM and Elong JG. 2011. Réponse Paysannes à l'expansion des Plantations de Palmier à huile dans la Région du Sud au Cameroun. In Elong J.G. (ed.) L'élite urbaine dans l'espace agricole africain. Paris: L'Harmattan. 212-224

Pledran O. 2012. Le Développement des Plantations de Palmiers à Huile au Cameroun (Enjeux pour un développement durable). Mémoire de Master1, Université de Lyon.

Rafflegeau S. (2008) Dynamique d'implantation et conduite technique des plantations villageoises de palmier à huile au Cameroun : facteurs limitant et raisons des pratiques. [Doctoral thesis]. Paris: AgroParisTech, CIRAD, IRAD.

Rafflegeau S, Michel-Dounias I, Tailliez B, Ndigui B and Papy F. 2010. Unexpected N and K nutrition diagnosis in oil palm smallholdings using references of high-yielding plantations. Agronomy Sustainability Development 30:777-87.

Rosenani AB, Basran RD, Zaharah AR and Zauyah S. 1996. A lysimetric study of the effects of $N \&$ $P$ fertilizer application on the decomposition and nutrient release of oil palm empty fruit bunches. PORIM Bulletin 33:1-11.

Sayer J, Ghazoul J, Nelson P and Boedhihartono AK 2012. Oil palm expansion transforms tropical landscapes and livelihood. Global Food Security 1(2):114-19.

Skurtis T, Ainache G and Simon D. 2010. Le financement du secteur de I'huile de palme : pourquoi les institutions financières de développement doivent continuer à investir en Afrique. OCL 17(6):400-3.

Syed RA. 1982. Insect pollination of oil palm. Feasibility of introducing Elaeidobius spp. Into Malaysia. In Pushparajah E and Chew PS. (eds). The Oil Palm in Agriculture in the Eighties. Kuala Lumpur: Incorporated Society of Planters.

Tonye J, Bayomock LA and Zoa JM. 2004.

Development of oil palm-based agro forests at the slash and burn agriculture project zone of Cameroon: agronomy and economics of the establishment phase. Cameroon Journal of Agricultural Sciences 1(1): 42-45.

World Bank Group (2012) Cameroon: Country brief. Available at http://go.worldbank.org/www. cedcameroun.org. 

CIFOR Working Papers contain preliminary or advance research results on tropical forest issues that need to be published in a timely manner to inform and promote discussion. This content has been internally reviewed but has not undergone external peer review.

The present study is an evaluation of the current strengths and weaknesses of the oil palm smallholder sector in Cameroon, or more precisely of the non-industrial sector, as some holdings owned by elites can reach hundreds of hectares. A randomized sample of oil palm producers was chosen after categorization into elites, migrants, natives and company workers (past and present) in four palm oil production basins in the southern part of the country. A total of 176 semi-structured questionnaires were administered. The production basins included: Eseka, Dibombari, Muyuka and Lobe. Results from the study revealed that elites owned larger average areas ( $41.3 \mathrm{ha}$ ) than the other categories of oil palm producers. All categories recorded low average plantation yields, ranging from 7 to $8.4 \mathrm{t} \mathrm{FFB/ha/year} \mathrm{(with} \mathrm{minimum} \mathrm{yields} \mathrm{of}$ $3 \mathrm{t} \mathrm{FFB/ha).} \mathrm{Though} \mathrm{the} \mathrm{elites} \mathrm{showed} \mathrm{better} \mathrm{bargaining} \mathrm{power} \mathrm{and} \mathrm{higher} \mathrm{income,} \mathrm{all} \mathrm{categories} \mathrm{of}$ producers faced similar problems such as the high cost of inputs with no governmental subsidies, difficulty in accessing loans with low interest rates and use of rudimentary working tools. Despite such weaknesses, the sector also demonstrated some strengths, for example causing little damage to the primary forest when compared to agro-industrial plantations, the availability of a domestic and subregional market for red palm oil, the availability of artisanal mills with low extraction rates and the ability to generate more income for the producers. There is a need for government policies that will strengthen the partnership between small and medium oil palm producers and agro-industries in order to comply with the poverty reduction strategy initiated by the government of Cameroon.

RESEARCH PROGRAM ON

Forests, Trees and Agroforestry
This research was carried out by CIFOR as part of the CGIAR Research Program on Forests, Trees and Agroforestry (CRP-FTA). This collaborative program aims to enhance the management and use of forests, agroforestry and tree genetic resources across the landscape from forests to farms. CIFOR leads CRP-FTA in partnership with Bioversity International, CATIE, CIRAD, the International Center for Tropical Agriculture and the World Agroforestry Centre. 